\title{
Late Pliensbachian (Early Jurassic) ammonites from Lac de Charmes (Haute-Marne, France): Systematic, biostratigraphy and palaeobiogeography
}

\author{
Jérémie BARDIN \\ Université Pierre et Marie Curie, \\ Centre de recherche sur la Paléodiversité et les Paléoenvironnements, \\ UPMC Univ. Paris 06, CR2P - UMR 7207 CNRS, MNHN, \\ 4 place Jussieu, Tour 46-56, 5ème étage, F-75005 Paris (France) \\ jbardin@mnhn.fr \\ Isabelle ROUGET \\ Fabrizio CECCA \\ Muséum national d'Histoire naturelle, \\ Centre de recherche sur la Paléodiversité et les Paléoenvironnements, \\ MNHN, CR2P - UMR 7207 CNRS, UPMC Univ. Paris 06, \\ 4 Place Jussieu, Tour 46-56, 5ème étage, F-75005 Paris (France) \\ isabelle.rouget@upmc.fr \\ fabrizio.cecca@upmc.fr
}

KEY WORDS

Mollusca, Cephalopoda, Ammonites, Amaltheidae, Jurassic, Late Pliensbachian, Haute-Marne, France, biostratigraphy.
Bardin J., Rouget I. \& Cecca F. 2013. - Late Pliensbachian (Early Jurassic) ammonites from Lac de Charmes (Haute-Marne, France): Systematic, biostratigraphy and palaeobiogeography. Geodiversitas 35 (2): 309-334. http://dx.doi.org/10.5252/g2013n2a2

\section{ABSTRACT}

The present paper deals with the systematic description of a rich and well-preserved ammonite fauna of the Late Pliensbachian, collected in two outcrops near the "Lac de Charmes" (Haute-Marne, France). In terms of ammonite zonation, the studied faunas indicate the Margaritatus and Spinatum Chronozones. Most of their subdivisions (subchronozones and zonules) have been recognized for the first time in this region. We propose a correlation with zonations established in close areas (Germany, Southern France). As already suggested on the literature, the possibility to further subdivide the Solare zonule in finner intervals is confirmed by our data. Within this zonule, we recognize a first interval with only Pleuroceras solare (Phillips, 1829), and a second one where this species occurs with several subspecies and where Pleuroceras spinatum (Bruguière, 1789) appears. Our results also confirm the possibility to subdivide more finely the Solare zonule firstly suggested by some authors. We recognize a first part with only Pleuroceras solare and a second one where this species present various subspecies and where Pleuroceras spinatum appears. Some points of view are given about Amaltheus gr. margaritatus Montfort, 1808, Pleuroceras gr. solare (Phillips, 1829) and the species Pleuroceras transiens (Frentzen, 1934). 


\begin{abstract}
RÉSUMÉ
Ammonites du Pliensbachien supérieur (Jurassique) du Lac de Charmes (HauteMarne, France): systématique, biostratigraphie et paléobiogéographie.

Cet article présente la description d'une faune riche et bien préservée d'ammonites du Pliensbachien supérieur collectée dans deux affleurements bordant le lac de Charmes (Haute-Marne, France). En termes de zonation, la faune indique les chronozones à Margaritatus et à Spinatum. Pour la première fois dans cette région, la plupart de leurs subdivisions ont été reconnues. Nous proposons une corrélation avec les biozonations établies dans les régions avoisinantes (Allemagne et Sud de la France). Nos résultats confirment la possibilité de subdiviser plus finement la zonule à Solare, ce qui avait été précédemment suggéré par d'autres auteurs. Nous reconnaissons un premier intervalle avec seulement Pleuroceras solare (Phillips, 1829) et un second où cette espèce présente plusieurs sous-espèces et où apparait Pleuroceras spinatum (Bruguière, 1789). Un point de vue est donné à propos de Amaltheus gr. margaritatus Montfort, 1808 et Pleuroceras gr. solare (Phillips, 1829) ainsi qu'à propos de l'espèce Pleuroceras

transiens (Frentzen, 1934).

\author{
Cephalopod \\ Ammonites, \\ Amaltheidae, \\ Jurassique, \\ Pliensbachien supérieur, \\ Haute-Marne, \\ France, \\ biostratigraphie. \\ MOTS CLÉS \\ Mollusca,
}

\section{INTRODUCTION}

According to palaeogeographic reconstructions, during the Pliensbachian Western Europe, namely the area that currently corresponds to England, France and Germany, was characterized by marine, neritic environments. Land areas were patchily dispersed in this huge shelf (Dercourt et al. 2000). The Anglo-Paris Basin was one of the most important epicontinental basin during the Mesozoic and in the Pliensbachian, ammonites are the most important fossil group for correlations between the different areas of the basin and also with the basins developed in Germany. Representatives of the Amaltheidae family characterize the ammonite assemblages.

According to the literature, Late Pliensbachian ammonites from the Paris Basin have been poorly studied from both palaeontological and biostratigraphical points of view. Dommergues et al. (2008) have recently described an ammonite fauna from a Pliensbachian outcrop located in Normandy (North of the Paris Basin), while south-west faunas have been well-studied in the Causses, Aveyron (Monestier 1913, 1916, 1928; Mattéi 1985; Meister 1989; Morard 2004). Tintant et al. (1961) presented Amaltheidae faunas collected all over the "Côte d'Or" (Burgundy,
France). Finally, Maubeuge (1961), after the publication of the geological map of Haute-Marne, wrote a paper on the Domerian-Toarcian Boundary near Langres (Haute-Marne). In contrast, English (Howarth 1955, 1957, 1958), Scotish (Howarth 1956) and German (Quenstedt 1858, 1885; Frentzen 1934, 1937; Jordan 1971; Urlichs 1977; Brandt $1985,1986)$ faunas have been thoroughly studied.

In this paper, we describe abundant and wellpreserved ammonites of the major part of the Late Pliensbachian collected bed by bed on the two different outcrops. The described fauna gives new insight for resolving problems that rise from comparing British and German faunas.

$\begin{array}{ll}\text { ABBREVIATIONS } \\ \mathrm{D} & \text { shell diameter; } \\ \text { gr. } & \text { group; } \\ \mathrm{h} & \text { whorl height starting from the umbilical } \\ & \text { seam up to the beginning of the forward } \\ & \text { projection of the rib; } \\ \mathrm{N} & \text { number of ribs; } \\ \mathrm{Ph} & \text { phragmocone diameter; } \\ \text { s.s. } & \text { sensu stricto; } \\ \mathrm{U} & \text { umbilicus diameter; } \\ \mathrm{Wb} & \text { whorl breadth; } \\ \mathrm{Wh} & \text { whorl height. }\end{array}$




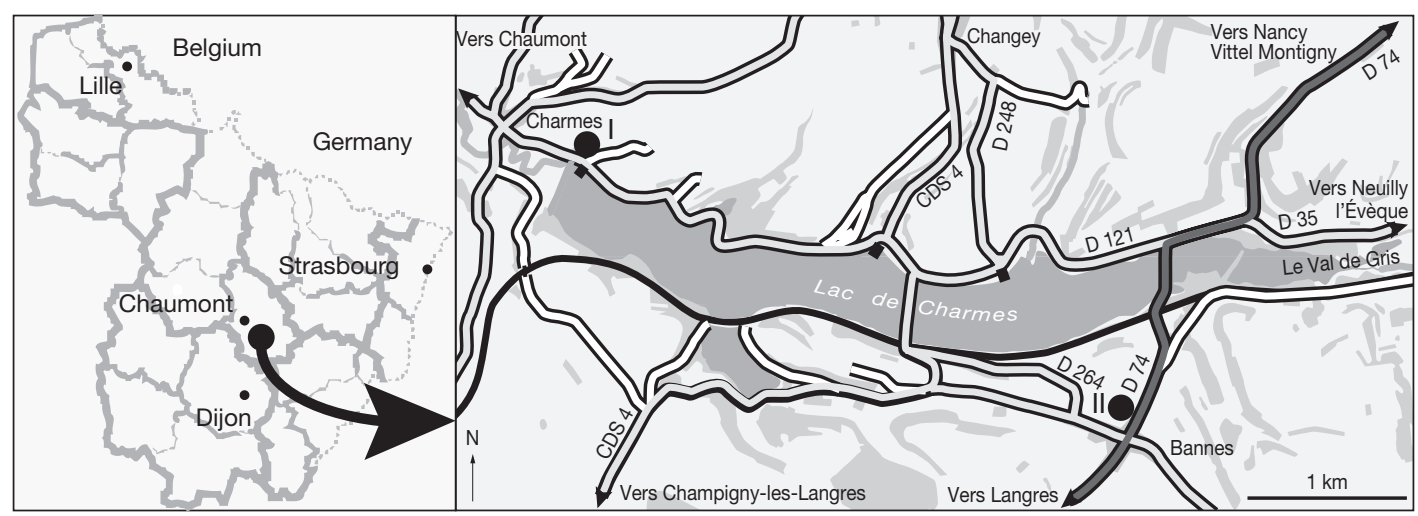

FIG. 1. - Location of the studied outcrops. The left map shows the location of the "Lac de Charmes" in the North-East France. The right map points the two studied outcrops.

\section{Institutions}

BM National History Museum, London (formerly

UPMC $\quad \begin{aligned} & \text { British Museum, Natural History); } \\ & \text { Université Pierre et Marie Curie, Paris. }\end{aligned}$

\section{LOCATION OF THE OUTCROPS}

Two outcrops have been studied (Fig. 1). The first one is on the northern edge of "Lac de Charmes" (Charmes, Haute-Marne, France), which is a reservoir of channels of Haute-Marne. Sampling was realized in a trench dug in the lateral extensions of the dam (GPS coordinates [Decimal]: 47.918418, 5.357029). It is unclear whether or not Maubeuge $(1958,1961)$ reported this outcrop because he mentioned the occurrence of Late Pliensbachian rocks due to the discovery of several specimens of Amaltheus Montfort, 1808 and Pleuroceras Hyatt, 1867. Unfortunately, information on the location of the outcrop is inadequate and its description is too brief. The second outcrop is located on the southern side of the "Lac de Charmes", near the road D74 (GPS coordinates [Decimal]: 47.907430, 5.400588). The outcrop is interrupted by a large tree whose roots have prevented vegetal growth at that point, revealing succession layers beneath. The two parts of the second outcrop (Fig. 2[IIa, IIb]) are separated by a fault, that is why we have distinguished the outcrops in two lithologic sections (Fig. 2).

\section{LITHOSTRATIGRAPHY \& FAUNAS}

The first outcrop studied consists of a 15 m-thick succession of alternating limestone and marls characterized by a detrital fraction of variable proportion (Fig. 2). The very base of the Upper Pliensabchian succession is covered. The succession has been measured from the lowest outcropping bed. We have distinguished five lithologic units. Almost all beds are fossiliferous. Faunas are mostly benthic (brachiopods, bivalves, gastropods, crustaceans). Nektonic taxa are represented by ammonites and belemnites. Fossils have been mostly collected from nodules. Observations in the lower part of unit A indicate that there is no difference in relative proportion of the different fossil groups in both nodules and matrix. Fossils are abundant, well preserved and undeformed within the nodules. Ammonite shells are recrystallised in the nodules, while they are preserved as inner moulds in the sandy limestones of the upper part of the section. Bivalves are often well preserved in the nodules. Outside nodules, fossils are rare, preserved as inner moulds and often crushed.

\section{OUTCROP I}

Unit A, from bed 1 to 5

$2.8 \mathrm{~m}$ of calcareous nodules surrounded by a matrix consisting in laminated silt and micaceous limestones. Nodules contain macrofossils (ammonites, bivalves), macrofossil debris (crinoids, sea-urchin spines) and 
microfossils. The matrix is probably the result of diagenetic dissolution while the nodules have been formed in an early diagenetic stage.

Bed 1. Abundant bivalves, belemnites, crinoids, sea-urchin spines;

Bed 2. Brachiopods, bivalves, belemnites, crinoids, sea-urchin spines;

Bed 3. Abundant bivalves, ammonites, belemnites, crinoids. Crustacean decapods and gastropods are less frequent. The identified ammonite species are: Amaltheus margaritatus Montfort, 1808 s.s. (21 ex.), Amaltheus gibbosus (Schlotheim, 1820) (12 ex.), Amauroceras ferrugineum (Simpson, 1855) (2 ex.), unidentifiable Amaltheus nuclei (15 ex.);

Bed 4. Abundant bivalves, crinoids, sea-urchin spines, ammonites: A. margaritatus s.s. (2 ex.), A. gibbosus (1 ex.), unidentifiable Amaltheus nucleus (1 ex.);

Bed 5. Abundant bivalves. Gasteropods and belemnites are less frequent. A. margaritatus s.s. (6 ex.), A. gibbosus, (5 ex.); Amaltheus sp. (7 ex.);

Unit $B$, from bed 6 to $8 a$

1 to $1.10 \mathrm{~m}$ of limestone and marly interbeds.

Bed 6. Gryphaea gr. Gigantean Sowerby, 1823, Amaltheus sp. (1 ex.);

Bed 7. Abundant bivalves, some brachiopods. Ammonites: Amaltheus sp. (1 ex.), Amaltheus salebrosum Hyatt, 1867 with inner whorl stade nudum (1 ex. reworked);

Unit $C$, from bed $8 b$ to $10 b$ :

$2.65 \mathrm{~m}$ of limestone and marly interbeds. The latter are relatively thick in this unit, spanning from 0.45 to 0.80 .

Bed 8a. Abundant bivalves (in particular pholads), some brachiopods, gasteropods, belemnites and crustacean decapods. Identified ammonites: Amaltheus sp.
(2 ex.) Amaltheus salebrosum (1 ex.), Pleuroceras transiens (Frentzen, 1937) (6 ex.), unidentifiable nuclei (8 ex.);

Bed 8b. Identified ammonites: Pleuroceras sp. (3 ex.), P. transiens (7 ex.);

Bed 10a. Some bivalves (Harpax spinosus (Sowerby, 1821)), belemnites. Identified ammonites: Pleuroceras sp. (1 ex.), P. transiens (1 ex. reworked);

\section{Unit D, from bed 11 to 15}

This unit is characterized by calcareous nodules surrounded by a matrix consisting of laminated silt.

Bed 12. Identified ammonites: Pleuroceras solare (Phillips, 1829) (1 ex. reworked);

Bed 13. Abundant bivalves (in particular $O x y$ toma (Meek, 1964)). Identified ammonites: A. gibbosus (1 ex.), Amaltheus salebrosum (2 ex., 1 reworked), P. solare (5 ex., one of them shows a remarkably compressed section), Pleuroceras solare trapezoidiforme (Maubeuge, 1951) (1 ex.), Pleuroceras spinatum (Bruguière, 1789) (1 ex.), unidentifiable nuclei of the genus Pleuroceras (2 ex.);

Bed 14. Abundant bivalves (in particular Oxytoma sp.). Identified ammonites: Pleuroceras sp. (2 ex.);

Unit E, from bed 16 to 19 :

$1.85 \mathrm{~m}$ of sandy limestone and silty interbeds.

Bed 16. Abundant bivalves, crinoids, some scaphopods. Identified ammonites: P. solare (1 ex.), P. cf. solare (1 ex.), P. solare trapezoidiforme (1 ex.), Pleuroceras solare solitarium (Simpson, 1855) (1 ex.), $P$. cf spinatum (1 ex.), unidentifiable nuclei of the genus Pleuroceras (3 ex.).

\section{OUTCROP II}

The second section consists of a 7.55 m-thick succession of alternating limestones and marls with an important detrital fraction similar to the upper part of the first outcrop. Three different lithogical units can be distinguished: 


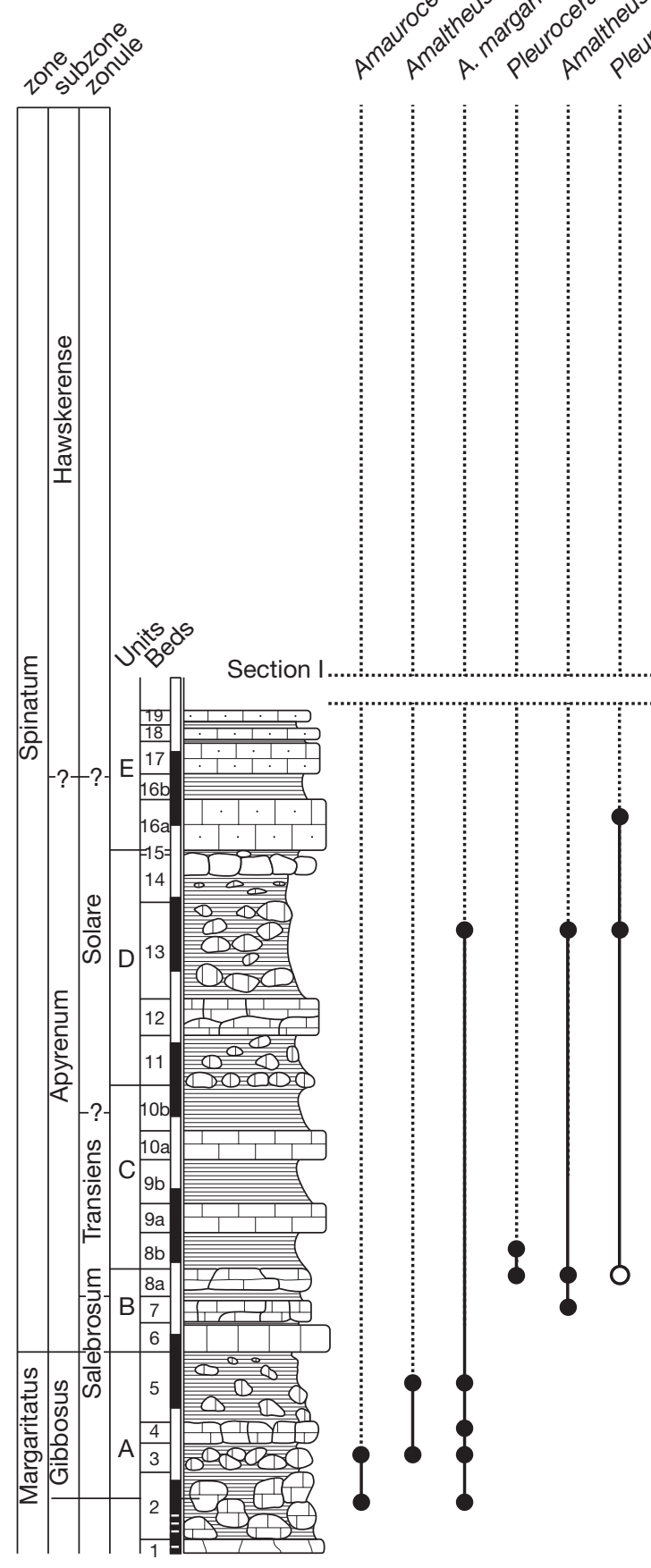

FIG. 2. - Lithologic sections of the two outcrops with the stratigraphic distribution of the identified ammonite species and correlation with the biostratigraphic zonation (Dommergues et al. 1997). The bottom-left section corresponds to section I and the two top-right ones to section II (Fig. 1). White circle: doubtful identification. 
TABLE 1. - Correlation between the studied section and the biozonations used in close areas: Germany (Frentzen 1934); Aveyron, Southern France (Mattéi 1985; Morard 2004).

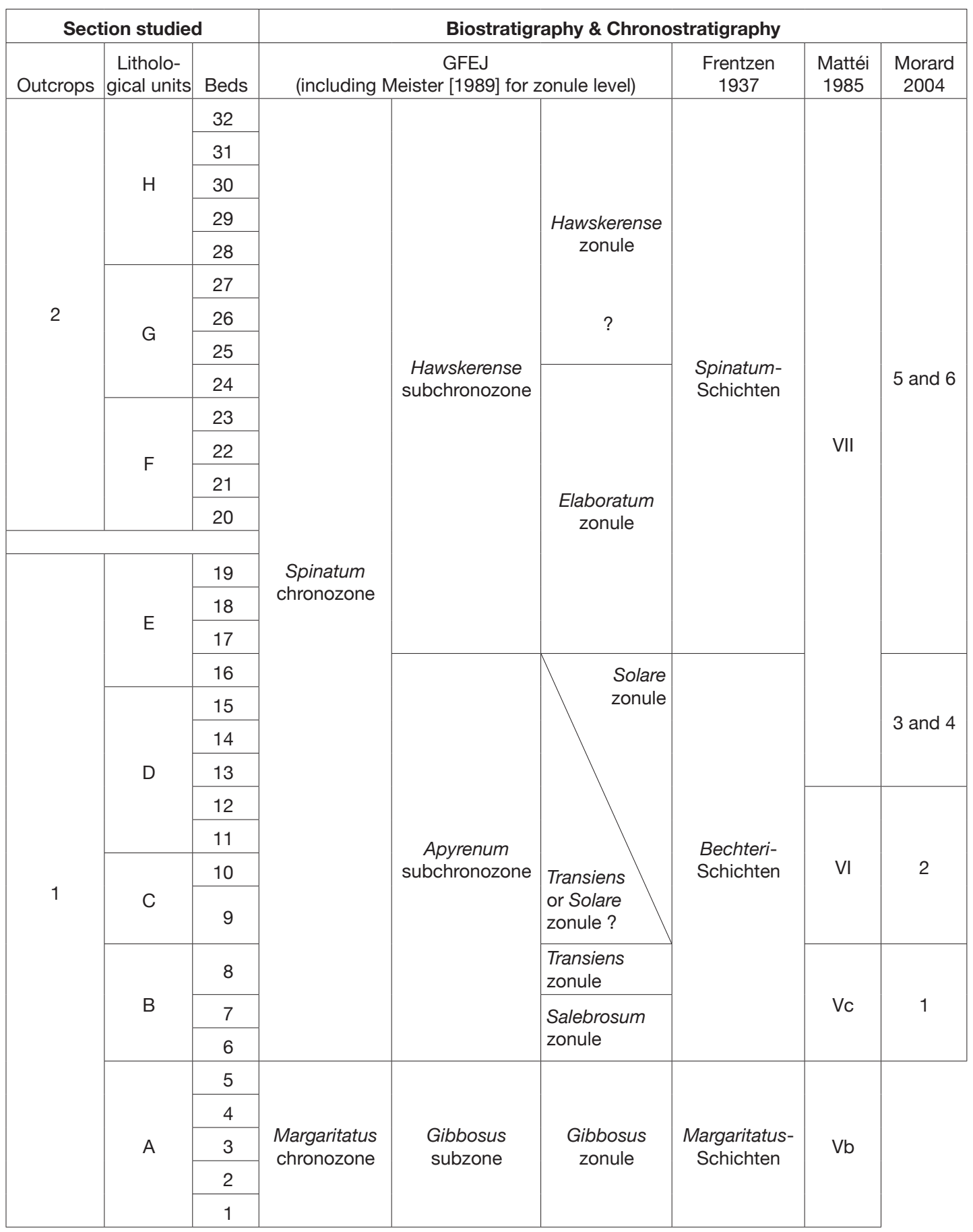




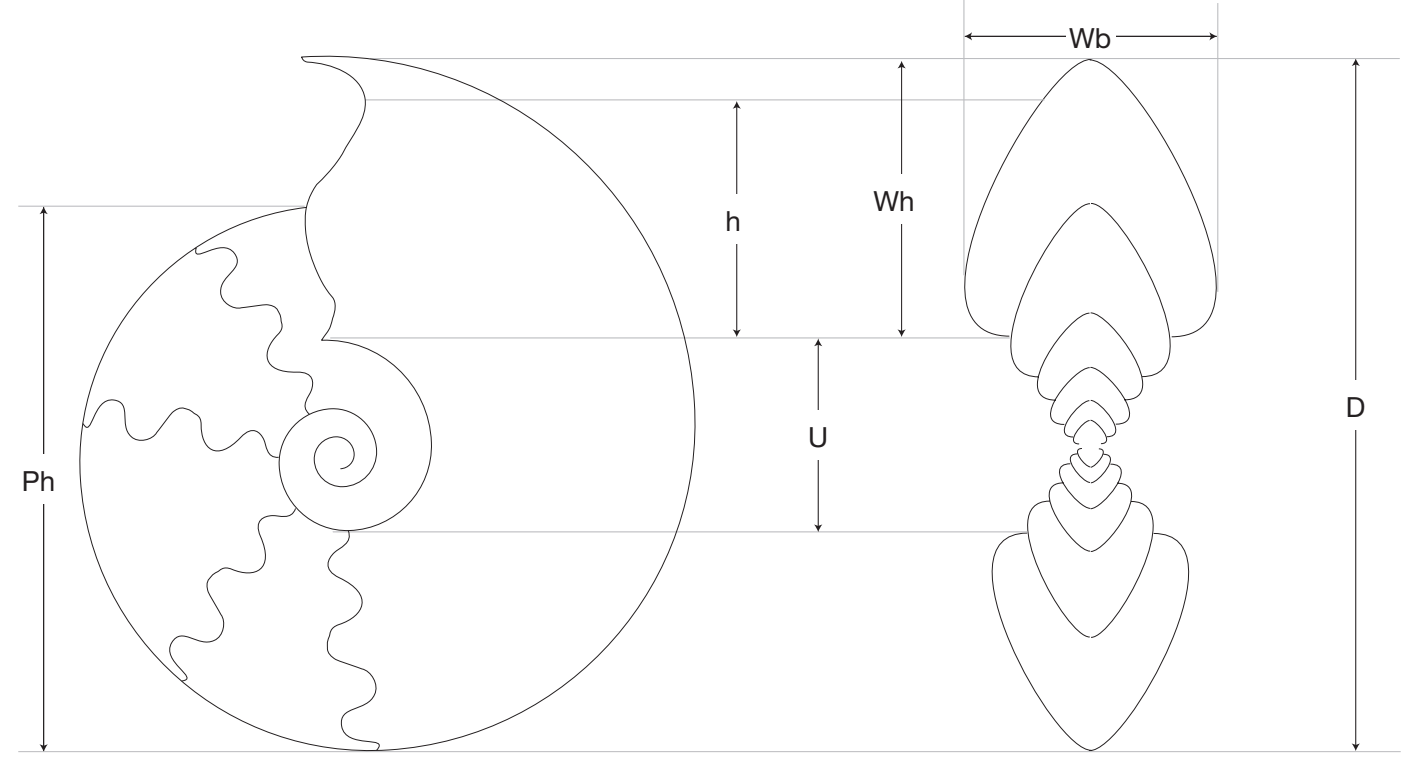

FIG. 3. - Abbreviations of the dimensional parameters used in the systematic descriptions: $\mathbf{D}$, shell diameter; $\mathbf{h}$, whorl height starting from the umbilical seam to the beginning of the forward projection of the rib; $\mathbf{P h}$, phragmocone diameter; $\mathbf{U}$, umbilicus diameter; Wh, whorl height; Wb, whorl breadth.

Unit F, from bed 20 to 23

$2.25 \mathrm{~m}$ of calcareous nodules surrounded by a matrix consisting of laminated silt and micaceous limestones.

Bed 20. Abundant bivalves (Oxytoma sp.), belemnites, crinoid, sea-urchin spines, some gastropods. Identified ammonites: P. spinatum (2 ex.);

Bed 21. Abundant bivalves (Pholadomya sp. and Oxytoma sp.), some burrows;

Bed 22. Abundant pholads. Identified ammonites: P. spinatum (1 ex.);

Bed 23. Abundant bivalves (in particular Pholadomya sp.), belemnites, unidentifiable nuclei of the genus Pleuroceras;

\section{Unit $G$, from bed 24 to bed 27}

$2.7 \mathrm{~m}$ of limestone and marly interbeds. Each bed is thick (around $1 \mathrm{~m}$ ).
Unit $H$, from bed 28 to 32

$2.6 \mathrm{~m}$ of more homogenous calcareous nodules surrounded by a matrix consisting in laminated silt and micaceous limestones. The bed 29 contains concentrated iron nodules with a diameter of four to seven $\mathrm{cm}$ and continuous iron oxide deposit.

Bed 28. Abundant bivalves (Mytilus sp., Oxytoma sp., pholads). Some brachiopods, gasteropods, wood particles. Identified ammonites: P. spinatum (1 ex.), unidentifiable nuclei of the genus Pleuroceras (2 ex.);

Bed 29. Abundant pholads, crinoids. Identified ammonites: $P$. cf. spinatum (2 ex. reworked);

Bed 30. Abundant bivalves (In particular Mytilus sp.). Identified ammonites: P. spinatum (1 ex.);

Bed 32. Identified ammonites: P. spinatum (1 ex. reworked). 
TABLE 2. - The different character states, taxa assigned to these morphologies and selected specimens from the literature.

\begin{tabular}{|c|c|c|c|c|c|c|}
\hline \multicolumn{4}{|c|}{ Morphology: distinctive characters } & \multirow[b]{2}{*}{$\begin{array}{c}\text { Frentzen } \\
1937\end{array}$} & \multirow[b]{2}{*}{$\begin{array}{l}\text { Further } \\
\text { works }\end{array}$} & \multirow[b]{2}{*}{ Specimens } \\
\hline shell & ventral area & $\begin{array}{l}\text { ventro-lateral } \\
\text { part of the rib }\end{array}$ & keel & & & \\
\hline \multirow{5}{*}{ 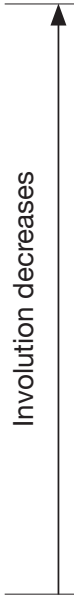 } & $\begin{array}{c}\text { keel with } \\
\text { more or less } \\
\text { pronounced sulci }\end{array}$ & straight & crenulated & & P. solare & \\
\hline & keel & straight & $\begin{array}{l}\text { chevrons slightly } \\
\text { connected to } \\
\text { ribs }\end{array}$ & A. bechteri & \multirow[t]{2}{*}{ P. transiens } & $\begin{array}{l}\text { Frentzen 1937: pl. IV, fig. 29, } \\
\text { 30, 32; Howarth 1958: } \\
\text { pl. IV, fig. 16-17; Mattéi } \\
\text { 1985: pl. XI, fig. 3, pl. XII, } \\
\text { fig. 3; Meister 1988: pl. 6, } \\
\text { fig. 8. }\end{array}$ \\
\hline & falgate & slightly curve & $\begin{array}{l}\text { chevrons con- } \\
\text { nected to ribs }\end{array}$ & \multirow{2}{*}{$\begin{array}{c}\text { A. margaritatus } \\
\text { var. } \\
\text { transiens }\end{array}$} & & $\begin{array}{l}\text { Frentzen 1937: pl. IV, } \\
\text { fig. 27; Meister 1988: } \\
\text { pl. 6, figs 4-5. }\end{array}$ \\
\hline & keel & curve & $\begin{array}{c}\text { chevrons slightly } \\
\text { connected to } \\
\text { ribs }\end{array}$ & & \multirow[t]{2}{*}{$\begin{array}{l}\text { A. marga- } \\
\text { ritatus }\end{array}$} & \multirow[t]{2}{*}{$\begin{array}{l}\text { Frentzen 1937: pl. IV, } \\
\text { figs 22-26; Urlichs 1977; } \\
\text { pl. 2, fig. } 1 .\end{array}$} \\
\hline & keel & curve & crenulated & A. margaritatus & & \\
\hline
\end{tabular}

\section{DISTRIBUTION OF THE OBSERVED TAXA}

The ammonite chronostratigraphy of the Late Pliensbachian in North-West European basins has been established on the basis of several studies (i.e. Frentzen 1934; Howarth 1958; Dean et al. 1961; Mouterde et al. 1971; Mattéi 1985). In this work, we follow the synthesis proposed by Dommergues et al. (1997). We use the distinction between horizon and zonule as developed by Page (2003). Our faunas are ascribed to the Margaritatus and Spinatum Chronozones and their subchronozonal subdivions. However, the succession of zonules recognized in our section within the Spinatum chronozone shows some differences. We proposed correlations (Table 1) with zonations of close outcrops to Haute-Marne (Frentzen 1934; Mattéi 1985; Morard 2004).

\section{MARGARITATUS CHRONOZONE}

Gibbosus subchronozone (Buckman 1918) as a hemera, Kuhn (1935) as a zone, Spath (1942) as a subzone. - Stratigraphic range: Bed 1 to 8 ;

- Index species: Amaltheus gibbosus;

- Correlating taxa: A. margaritatus, A. gibbosus, A. ferrugineum;

\section{Comments}

In the northern part of the NW European area, only Amaltheidae are found and no subdivisions are defined. This is also the case of our outcrops. The thickness of the subchronozone cannot be given because only the top is exposed.

\section{SPINATUM CHRONOZONE}

Apyrenum subchronozone (Spath 1942).

- Stratigraphic range: Bed 7 to 16a;

- Index species: Pleuroceras apryrenum;

- Correlating taxa: P. transiens, A. salebrosum, P. gr. solare, P. spinatum;

\section{Comments}

Pleuroceras apyrenum (Buckman, 1911) has not been found in our outcrops, the Apyrenum subchronozone has been recognized thanks to the correlating faunas. The Apyrenum subchronozone is usually subdivided into three zonules: Salebrosum zonule (Meister 1987); Transiens zonule (Comas-Rengifo 1985, emend. Meister 1987) and Solare zonule (Mattéi 1971 in Mouterde et al. 1971 emend. Meister 1987). The first two cannot be distinguished in our succession because both $P$. salebrosum and $P$. tran- 
siens are found in bed 8 . However, we have found in bed 7, a specimen resembling to the one figured by Frentzen (1937: pl. IV, fig. 31) and ascribed to $P$. bechteri (Frentzen, 1934). If all the morphologies of the latter are ascribed to $A$. salebrosum, as suggested by some authors, (Howarth 1958; Meister 1989) the Salebrosum zonule can be recognized. According to Morard (Thesis 2004), these two zonules cannot be distinguished in the Causses basin where Meister (1989) established them. The existence of these two zonules is doubtful. The Solare zonule is recognized from bed 13, where P. solare become frequent and the first occurrence of $P$. spinatum is observed, up to bed 16. However, the range of the Solare zonule could reach bed 8 where a specimen tentatively identified as $P$. solare was found. This would be consistent with the occurrence of peculiar $P$. solare subspecies in beds 13 and 16, which usually are found in the upper part of the Apyrenum subchronozone (Frentzen 1937; Howarth 1958). According to Howarth (1958), the Apyrenum subchronozone corresponds to the -Schichten of Frentzen (1934). We agree with his conclusion because the major part of the ammonites that Frentzen ascribed to $P$. bechteri corresponds to P. solare (Table 2). Our observations confirm Morard's hypothesis that the Solare zonule could be subdivided more finely. We can distinguish a first range with only $P$. solare and a second one with some different subspecies of $P$. solare (trapezoidiforme \& solitarium) and the first occurrence of $P$. spinatum respectively corresponding to his second and third assemblages (Morard 2004: 74, 75, text-fig. 3.18).

\section{HAWSKERENSE SUBCHRONOZONE}

- Stratigraphic range: Bed 17 to 32.

- Index species: Pleuroceras hawskerense.

- Correlating taxa: P. spinatum.

\section{Comments}

Pleuroceras hawskerense widely occurs in England, where it is more frequent and more reliably identified than in other areas. In England the stratigraphic range of $P$. spinatum is very similar to that of $P$. hawskerense. According to Howarth (1958), these two species have the same age and the Hawskerense subchronozone can be characterized by the occurrence of some strongly ornamented morphotypes of P. spinatum. In Haute-
Marne, we have found several strongly ornamented specimens of $P$. spinatum in our second outcrop. Mattéi (1985) observed a similar situation in the last assemblage of the Domerian succession called "Dom. VII". In the second half of this succession, the ornamentation of the specimens of P. spinatum is stronger than the one of the specimens occurring in the first half. Mattéi (1985) also noticed that specimens of $P$. spinatum become more frequent than the specimens of $P$. solare. This abundance of $P$. spinatum and the lack of faunal elements of the Solare subchronozone allow us to recognize the Hawskerense subchronozone. As a consequence, we have not been able to recognize subchronozonal subdivisions. After our intensive field work in Haute-Marne, Maubeuge's outcrop and the Pliensbachian-Toarcian boundary in particular have not been found. Despite Maubeuge's work (1961) in Haute-Marne, the Pliensbachian-Toarcian boundary cannot be observed and we cannot conclude on the completeness of the Hawskerense subchronozone in this area.

\section{SYSTEMATIC DESCRIPTIONS}

All collected ammonites belong to the family Amaltheidae Hyatt, 1867. The presence of a crenulated keel (see description) is the most distinctive character (synapomorphy) despite the fact that's taxa some representatives lost it secondarily. The hypothesis of Amaltheidae monophyly seems very robust. Authors currently recognize three genera: Amaltheus Montfort, 1808; Amauroceras Buckman, 1913; Pleuroceras Hyatt, 1867. However, within each of these genera, taxonomy is not stable or well-established. Several monographs on Amaltheidae have been taken into account for the present work (Quenstedt 1882-1885; Frentzen 1937; Howarth 1958; Mattéi 1985; Meister 1989). Howarth's monograph (1958) is currently the most used. All specimens' measurements (Fig. 3) are reported in Table 3. Synonymy lists are not exhaustive for frequently reported taxa (e.g., Amaltheus margaritatus), specimens have been selected to depict the morphological variation of the considered taxon, these synonymy lists work has hypodigms. All specimens are housed in the paleontological collections of the University Pierre et Marie Curie. 
TABLE 3. - Measurements for each of the studied specimens. Abbreviations: $\mathbf{D}$, shell diameter; Ph, phragmocone diameter; U, umbilical diameter; Wh, whorl height; $\mathbf{h}$, whorl height starting from the umbilical seam to the beginning of the forward projection of the rib; Wb, whorl breadth; N, number of ribs per whorl at a given diameter; B, bed number. In "Ph" column, "P" means that the specimen is entirely septate. The measures in brackets indicate that a given parameter has been measured at the diameter different to the one indicated in the "D" column. The bold UPMC numbers highlight specimens of Figures 4 to 8.

\begin{tabular}{|c|c|c|c|c|c|c|c|c|c|}
\hline N'UPMC & Species & D & $\mathrm{Ph}$ & U & $\mathbf{W b}$ & Wh & h & $\mathbf{N}$ & B \\
\hline UPMC-100 & A. gibbosus & 34.95 & 30.39 & 14.42 & 11.27 & 12.66 & 9.51 & 19 & 3 \\
\hline UPMC-103 & A. gibbosus & 22.12 & $\mathrm{P}$ & 7.55 & 7.66 & 9.16 & 7 & 19 & 3 \\
\hline UPMC-106 & A. gibbosus & 15.5 & $P$ & 4.46 & 5.15 & 6.42 & 5.08 & 16 & 3 \\
\hline UPMC-107 & A. gibbosus & 16.5 & $\mathrm{P}$ & 5.39 & 7.08 & 7.02 & 5.16 & 14 & 3 \\
\hline UPMC-114 & A. gibbosus & 32.25 & 23.18 & 11.86 & 7.76 & 11.28 & 8.06 & 22 & 3 \\
\hline UPMC-116 & A. gibbosus & 15.48 & $\mathrm{P}$ & 4.46 & 5.71 & 6.46 & 5.02 & 18 & 3 \\
\hline UPMC-126 & A. gibbosus & 44.52 & 42.63 & 16.36 & 11.36 & 18.42 & 14 & 24 & 3 \\
\hline UPMC-128 & A. gibbosus & 34.23 & 29.5 & 10.85 & 8.99 & 15.04 & 10.9 & 22 & 3 \\
\hline UPMC-132 & A. gibbosus & 30.34 & $?$ & 11.65 & 8.85 & 11.72 & 8.35 & 22 & 3 \\
\hline UPMC-138 & A. gibbosus & 66.91 & $\mathrm{P}$ & 23.24 & 17.06 & 27.75 & 20.64 & 20 & 3 \\
\hline UPMC-146 & A. gibbosus & 32.90 & $?$ & 11.63 & $?$ & 12.78 & 10.04 & 21 & 5 \\
\hline UPMC-152 & A. gibbosus & 34.07 & $?$ & 12.24 & ? & 14.21 & 10.03 & 22 & 5 \\
\hline UPMC-101 & A. margaritatus & 37.4 & 28.5 & 12.65 & 8.46 & 16.19 & 12.01 & 25 & 3 \\
\hline UPMC-102 & A. margaritatus & 44.95 & $?$ & 15.8 & 10 & 18.45 & 13.37 & 23 & 3 \\
\hline UPMC-104 & A. margaritatus & 40.62 & ? & 10.85 & $8.11(33.25)$ & 18.05 & 11.54 & 24 & 3 \\
\hline UPMC-105 & A. margaritatus & 14.54 & $\mathrm{P}$ & 4.21 & 4.63 & 6.66 & 0.44 & 21 & 3 \\
\hline UPMC-108 & A. margaritatus & 24.5 & ? & 7.75 & 6.4 & 11.48 & 8.86 & 20 & 3 \\
\hline UPMC-109 & A. margaritatus & 20.08 & $P$ & 6.64 & 7.1 & 9.18 & 5.99 & 18 & 3 \\
\hline UPMC-110 & A. margaritatus & 26.5 & $?$ & 8.5 & ? & 12.6 & 9.22 & 24 & 3 \\
\hline UPMC-120 & A. margaritatus & 18.4 & $?$ & 5.62 & $?$ & 7.7 & 5.82 & 21 & 3 \\
\hline UPMC-127 & A. margaritatus & 29.75 & $P$ & 8.72 & $?$ & 12.54 & 8.62 & 20 & 3 \\
\hline UPMC-129 & A. margaritatus & 19.37 & $?$ & 5.51 & $?$ & 8.99 & 6.42 & 19 & 3 \\
\hline UPMC-130 & A. margaritatus & 20.76 & $?$ & 6.97 & $?$ & 8.22 & 5.9 & 19 & 3 \\
\hline UPMC-131 & A. margaritatus & 30.19 & $?$ & 9.15 & $?$ & 13.31 & 9.19 & 20 & 3 \\
\hline UPMC-133 & A. margaritatus & 15 & $\mathrm{P}$ & 4.24 & 5.42 & 6.16 & 4.67 & 16 & 3 \\
\hline UPMC-135 & A. margaritatus & 14.52 & $P$ & 3.35 & $?$ & 6.46 & 4.48 & 22 & 3 \\
\hline UPMC-137 & A. margaritatus & 68.7 & $?$ & 17.09 & 13.42 & 28.63 & 18.93 & 31 & 3 \\
\hline UPMC-143 & A. margaritatus & 28.65 & ? & 8.53 & 8.27 & 12.7 & 9.93 & 21 & 3 \\
\hline UPMC-145 & A. margaritatus & 36.26 & 33.07 & 10.52 & 9.28 & 16.25 & 11.64 & 22 & 4 \\
\hline UPMC-147 & A. margaritatus & 37.44 & 27.19 & 10.81 & 8.42 & 16.5 & 11.8 & 26 & 5 \\
\hline UPMC-149 & A. margaritatus & 38.91 & ? & 12.07 & 7.55 & 17.7 & ? & $?$ & 5 \\
\hline UPMC-151 & A. margaritatus & 33.34 & ? & 9.23 & $?$ & 15.09 & $?$ & $?$ & 5 \\
\hline UPMC-159 & A. margaritatus & 23.45 & ? & 7.7 & ? & 9.11 & ? & $?$ & 5 \\
\hline UPMC-187 & A. margaritatus & 51.95 & $?$ & 15.3 & 11.97 & 21.71 & 17.08 & 25 & 13 \\
\hline UPMC-192 & A. salebrosum & 38.01 & $?$ & 10.64 & $?$ & 17.15 & 12.47 & $?$ & 13 \\
\hline UPMC-121 & A. sp. & 20.13 & $?$ & 6.48 & $?$ & 8.44 & 6.04 & $?$ & 3 \\
\hline UPMC-141 & A. sp. & 13.52 & $\mathrm{P}$ & 4.32 & ? & 5.82 & 4.22 & $?$ & 3 \\
\hline UPMC-142 & Juvenile & 19.69 & $?$ & 5.63 & 5.89 & 8.68 & 5.97 & 21 & 3 \\
\hline UPMC-162 & Juvenile & 18.12 & $\mathrm{P}$ & 5.53 & 5.58 & 7.26 & 5.08 & $?$ & 5 \\
\hline UPMC-196 & Juvenile & 8.53 & $\mathrm{P}$ & 2.66 & 3.4 & 3.6 & 2.5 & 26 & 13 \\
\hline UPMC-197 & Juvenile & 18.1 & $\mathrm{P}$ & 5.59 & 5.62 & 7.38 & 5.83 & 23 & 13 \\
\hline UPMC-205 & Juvenile & 14.38 & $\mathrm{P}$ & 4.87 & 4.45 & 5.8 & 4.41 & 18 & 16 \\
\hline UPMC-190 & P. solare & 37.66 & ? & 14.24 & 10.94 & 12.16 & ? & 25 & 13 \\
\hline UPMC-194 & P. solare & 37.94 & ? & 12.06 & 9.51 & 14.99 & 12.39 & $?$ & 13 \\
\hline UPMC-200 & P. solare & 37.87 & 32.13 & 13.71 & $?$ & 13.79 & 11.25 & ? & 16 \\
\hline UPMC-203 & P. solare solitarium & 37.32 & $\mathrm{P}$ & 15.7 & 9.36 & 12.55 & 10.72 & $?$ & 16 \\
\hline UPMC-191 & $\begin{array}{l}\text { P. solare } \\
\text { trapezoidiforme }\end{array}$ & 38.17 & $?$ & 13.49 & $?$ & 12.91 & $?$ & 26 & 13 \\
\hline UPMC-202 & $\begin{array}{l}\text { P. solare } \\
\text { trapezoidiforme }\end{array}$ & 36.03 & $?$ & 12.34 & 7.98 & 13.95 & $?$ & 25 & 16 \\
\hline UPMC-166 & P. transiens & 32.1 & 25.44 & 10.16 & ? & 11.82 & 9.98 & ? & 8 \\
\hline UPMC-167 & P. transiens & 18.33 & ? & 5.49 & $?$ & 7.22 & $?$ & $?$ & 8 \\
\hline
\end{tabular}


TABLE 3. - Continuation.

\begin{tabular}{llcccccrrr}
\hline N.UPMC & Species & $\mathbf{D}$ & $\mathbf{P h}$ & $\mathbf{U}$ & $\mathbf{W b}$ & $\mathbf{W h}$ & $\mathbf{h}$ & $\mathbf{N}$ & $\mathbf{B}$ \\
\hline UPMC-174 & P. transiens & 36.29 & $?$ & 12.15 & 8.86 & 13.81 & 11.25 & $?$ & $8-9$ \\
UPMC-175 & P. transiens & 38.58 & 28.77 & 13.69 & 9.05 & 13.78 & 10.71 & 26 & $8-9$ \\
UPMC-176 & $P$. transiens & 28.72 & $?$ & 9.5 & $?$ & 11.99 & 9.65 & $?$ & $8-9$ \\
UPMC-177 & P. transiens & 13.64 & $?$ & $?$ & 4.53 & 6.87 & 5.05 & $?$ & $8-9$ \\
UPMC-180 & P. transiens & 20.73 & $P$ & 6.67 & 6.44 & 8.31 & 6.04 & $?$ & $8-9$ \\
UPMC-182 & P. transiens & 20.7 & $?$ & 6.32 & 5.08 & 8.7 & $?$ & $?$ & $8-9$ \\
UPMC-189 & P. spinatum & 50.86 & $?$ & 21.45 & 13.87 & 16.99 & 14.23 & $?$ & 13 \\
UPMC-208 & P. spinatum & 63.6 & $?$ & 28.04 & $?$ & 19.8 & 19.8 & 21 & 20 \\
UPMC-220 & P. spinatum & 58.16 & $?$ & 27.82 & $16.21(53.61)$ & $16.8(53.61)$ & $16.8(53.61)$ & $?$ & 32 \\
\hline
\end{tabular}

Family AMALTHEIDAE Hyatt, 1867

\section{Genus Amaltheus Montfort, 1808}

Nordamaltheus Repin in Efimova et al., 1968: 111. - Type species: Amaltheus (Nordamaltheus) viligaensis (Tuchkov, 1954).

TYPE SPECIES. - Amaltheus margaritatus Monfort, 1808 (by original designation).

Stratigraphic Distribution. - Late Pliensbachian, Margaritatus chronozone, base of Stockesi subchronozone up to middle Spinatum zone, top of Apyrenum subchronozone. Haute-Marne: bed 3 to 13.

DiAgnosis. - The more distinctive character is the crenulated keel made by more or less inclined chevrons. The shell is involute to moderately involute. Whorl section is subtriangular, often compressed (subovate to subcircular in some forms and at small diameter). The ribs are bifurcated, trifurcated or quadrifurcated. Between the point of branching and the beginning of the chevrons (ventral) the coarseness of the ribs is often reduced. Chevrons are two to four times more numerous than the ribs. Ornamentation is highly variable and covaries with the curvature of the flanks: evolute forms develop strong ribs and spines, while compressed and involute forms are almost smooth. Therefore, lateral tubercles are common in the young specimens with low and rounded whorls. At the end of the growth all Amaltheus species show the compression of the whorls and a reduction of the radial ornamentation (including crenulation strength of the keel). A trifid first lateral saddle and a first, deep trifid lateral lobe characterize the suture. Auxiliary saddle is well developed in the ventral lobe.

\section{DISCUSSION}

The combination of crenulated keel and triangular whorl section allows the distinction of the genus
Amaltheus from the genus Pleuroceras, which develops some quadrilateral whorls.

Amaltheus margaritatus Montfort, 1808

(Figs 4A, B; 5A, B; 6F, G; Table 3)

Amaltheus margaritatus Montfort, 1808: 90. — d'Orbigny 1844: 246, pl. 67, figs 1-3; non pl. 68, figs 1-8. — Wright 1882: 397, pl. 53, fig.1, pl. 54, figs 1-3, text-fig. 8. Howarth 1958: 15, 16, text-figs 8, 9. - Fischer 1994: 63, pl. 27, fig. 1a-c.

Ammonites acutus Sowerby, 1813: 51, pl. 17, fig. 1.

Ammonites amaltheus Schlotheim, 1813: 101.

Ammonites depressus Simpson, 1843; figured in Buckman S. S. 1911: pl. 25, figs 1, 2.

Ammonites Sedgwickii Buckman J., 1845: 40; figured in Buckman S. S. 1918: pl. 125 (nomen nudum).

Ammonites amaltheus nudus Quenstedt, 1849: 94, pl. 5, figs 11, 12 (refigured in Frentzen 1937: pl. I, fig. 28).

Ammonites foliaceus Giebel, 1852: 540.

Ammonites amaltheus compressus Quenstedt, 1885: 327 , pl. 41, fig. 17; pl. 42, fig. 8 .

Amaltheus (Amaltheus) margaritatus-Tintant et al. 1961: pl. I, figs 6, 7.

TYPE MATERIAL. - The specimen figured by Monfort (1808) is presumed to be lost. Howarth designated the specimen BM 37039 as neotype (1958: 15, text-fig. 8).

Specimens AVAilable. - UPMC-101, 102, 104,105, $108-110,112,118,120,127,129-131,133,136,137$, $143-145,147,149,151,155,158,159,222-224$. 
Stratigraphic Distribution. - Late Pliensbachian, Margaritatus chronozone, base of Subnodosus subchronozone up to the middle of the Spinatum chronozone, top of Apyrenum Subzone. Haute-Marne: bed 3 to bed 13 .

Geographic Distribution. - South-East France, Causses (Monestier 1913, 1916, 1928; Mattéi 1985; Meister 1989; Morard 2004); eastern France, Burgundy (Tintant et al. 1961; Lablanche et al. 1997) and Haute-Marne (this work); North-West France, Paris Basin, Normandy (Dommergues et al. 2008); North-West Germany (Jordan 1971); SouthWest Germany (Frentzen 1934; Urlichs 1977); England (Howarth 1958); Scotland (Howarth 1958); Bulgaria (Stephanov 1960); Iran, Alborz Range (Seyed-Emami et al. 2008); Georgia (Topchishvili 1998); Portugal (Mouterde 1967); Morocco, Moyen-Atlas (Morard 2004); Siberia (Dagis 1976); Italy, Lombardy Basin (Wiendenmayer 1980); North America, Stikinia allochthonous terrane and Arctic-Alaska craton (Smith et al. 2001); Tunisia (Fauré et al. 2007).

\section{DESCRIPTION}

The whorl section is compressed with the whorl heigth matching at least twice the whorl breadth. The umbilical edges are angular. Ribbing is weak and does not develop any spines or tubercles. These diagnostic character states must be observed on adult whorls because some $A$. margaritatus have inner whorls $(\mathrm{D}<2-3 \mathrm{~cm})$ showing the morphologies of $A$. gibbosus or $A$. gloriosus.

\section{DISCUSSION}

This is the most common Amaltheidae species. Amaltheus margaritatus can be distinguished from the other Amaltheus species because of the absence of spines or tubercles and the important reduction of ribbing strength starting from a diameter of around $25 \mathrm{~mm}$.

\section{Amaltheus gibbosus (Schlotheim, 1820) (Figs 4C-F; 5I, J; Table 3)}

Ammonites amaltheus gibbosus Schlotheim, 1820: 66. Amaltheus turgidus Hyatt, 1867: 90.

Amaltheus margaritatus var. muntjanae Tietze, 1872: 102, pl. 2, fig. 5.

Amaltheus gibbosus - Howarth 1958: 17, text-fig. 10.

Amaltheus (Amaltheus) gibbosus - Tintant et al. 1961: pl. 1, fig. 4. - Mattéi 1985: pl. 1, fig. 1H.
Type Material. - The lectotype chosen by Howarth (1958) is the specimen n'2.4.Q.K. (Berlin University Museum) figured in Schlotheim (1820: 66). It is refigured in Howarth (1958: 17, text-fig. 10).

SPeCimenS AVAILABle. - UPMC-100, 103, 106, 107 , $111,114,115,116,126,128,132,138,146,148$, $150,152,153$.

StratigraPhicAl Distribution. - Late Pliensbachian, Margaritatus chronozone, base of Gibbosus subchronozone up to the top of Gibbosus subchronozone. Haute-Marne: bed 3 to bed 5 .

Geographic distribution. - South-East France, Causses (Monestier 1913, 1916, 1928; Mattéi 1985; Meister 1989; Morard 2004); North-West France, Paris Basin, Normandy (Dommergues 2008); eastern France, Burgundy (Tintant et al. 1961; Lablanche et al. 1997) and Haute-Marne (this work); North-West Germany (Jordan 1971); South-West Germany (Frentzen 1934; Urlichs 1977); Austria, northern Calcareous Alps (Meister \& Böhm 1993); England and Scotland (Howarth 1958).

\section{DESCRIPTION}

The shell is moderately evolute with a subelliptic whorl section. Up to a diameter of about $20 \mathrm{~mm}$, whorls are larger than high and a tubercle is present on each rib (stadium coronatum, Quenstedt, 1885). From a diameter of $20 \mathrm{~mm}$, a strong tubercle develops near the ventro-lateral edge every two or three ribs (stadium gibbosum, Schlotheim, 1820). Sometimes a later ontogenetic stage occurs, tending towards the character states of $A$. margaritatus, i.e. lack of tubercles and ovate whorl section (stadium nudum [Quenstedt 1885]).

\section{DISCUSSION}

Amaltheus gibbosus differs from $A$. salebrosum because of the stronger involution and its higher whorl section. The adult size of $A$. gibbosus is smaller than that of $A$. salebrosum. Amaltheus gibbosus differs from A. gloriosus because of both the stronger involution and the presence of the stadium gibbosum, which consists of a tubercle every two or three ribs.

\section{Amaltheus salebrosum Hyatt, 1867}

(Figs 5K, L; 6H, I; Table 3)

Amaltheus salebrosus Hyatt, 1867: 90 (nom. nov. for Quenstedt, 1849: 95, pl. 5, fig. 4b; 1856: 168, pl. 20, fig. 8). 


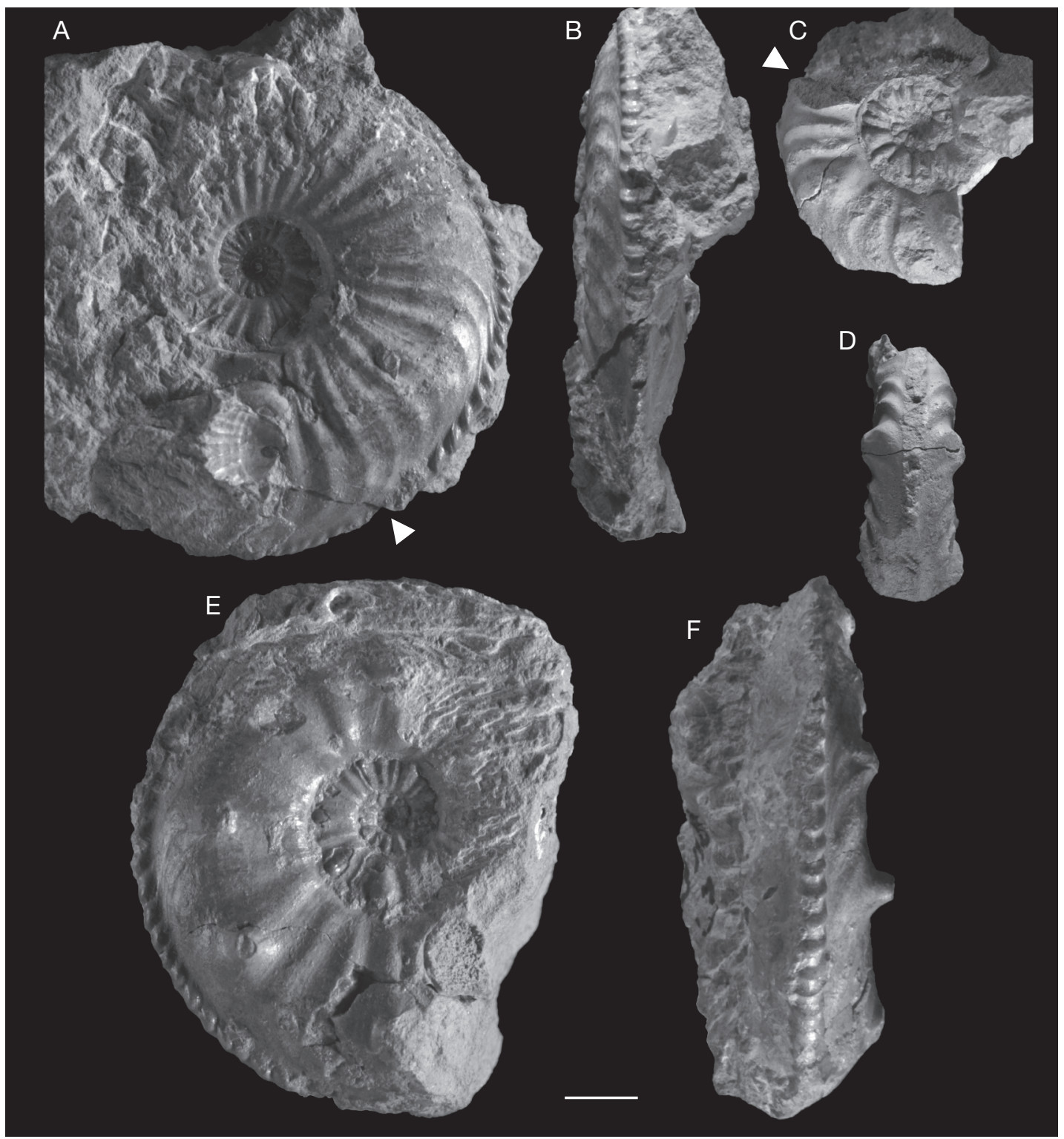

FIG. 4. - Amaltheus margaritatus Montfort, 1808: A, B, specimen UPMC-137, Outcrop 1, bed 3, Amaltheus gibbosus (Schlotheim, 1820); C, D, specimen UPMC-100, Outcrop 1, bed 3; E, F, specimen UPMC-138, Outcrop 1, bed 3. Scale bar: $1 \mathrm{~cm}$. The arrows indicate the beginning of the body chamber.

Ammonites amaltheus spinosus Quenstedt, 1849: 95, pl. 5, fig. 4b; 1856: 168, pl. 20, fig. 8; 1885: 321, 322, pl. 41 , fig. 5.

Amaltheus armiger Buckman, 1911 (nom. nov. for Quenstedt 1885: 321, 322, pl. 41, fig. 5).
Amaltheus bechteri Frentzen, 1934: 40-42 (nom. nov. for Quenstedt 1885: 321, 322, pl. 41, fig. 5); 1937: pl. 5, figs $6,7,10-12$.

Pleuroceras salebrosum - Howarth 1958: 34, text-fig. 13. Tintant et al. 1961: pl. 1, fig. 10. 
Amaltheus postremus Mattéi, 1985: 117, pl. 12, fig. 1.

Type MATERIAL. - Buckman designated Quenstedt 1856: 168, pl. 20, fig. 8 lectotype of A. salebrosum. This specimen is assumed to be lost, thus Howarth (1958) designated a topotype as neotype (Tübingen Museum Ce 5/41/5, text-fig. 13).

Specimens aVAilable. - UPMC-225, 173, 188, 192.

Stratigraphical Distribution. - Upper Gibbosus subchronozone - base of Hawskerense subchronozone. Haute-Marne: bed 7 to 13 .

Geographic distribution. - England and Scotland (Howarth 1958); eastern France, Burgundy (Tintant et al. 1961; Lablanche et al. 1997) and Haute-Marne (this work); North-west Germany (Jordan 1971); South-West Germany (Frentzen 1934); South-East Germany (Hoffman et al. 2007); Italy, Lombardy Basin (Wiendenmayer 1980).

\section{DESCRIPTION}

Evolute shell with a whorl section similar to that of the inner whorls of Pleuroceras (presence of sulci formed on both sides of the keel by strong ribbing). In the last whorls, the section is nearly circular. Strong tubercles near the ventro-lateral edge are developed every two or three ribs. The expression of this tuberculate stage seems to be very irregular. In the classical specimens of A. salebrosum (i.e. Neotype: Howarth 1958: textfig. 13), tubercles develop all along the growth. In some specimens, especially German faunas (Quensted 1885; Frentzen 1937), this stage can be reduced to only three tubercules (i.e. Frentzen 1937: pl. VI, fig. 2).

\section{DisCUSSION}

This species can be confused with $A$. gibbosus, which does not exceed a diameter of $70 \mathrm{~mm}$, whereas A. salebrosum can reach $150 \mathrm{~mm}$. Amaltheus salebrosum is more evolute than $A$. gibbosus in the adult whorls. From the stratigraphic point of view, $A$. salebrosum appears together with $P$. transiens after the disappearance of $A$. gibbosus.

\section{Genus Amauroceras Buckman, 1913}

Proamaltheus Lange, 1932: 238. — Type species: Amaltheus wertheri (Lange, 1932).

TYPE SPECIES. - Ammonites ferrugineus Simpson, 1855 (by subsequent designation of Buckman [1913])
STRATigraphical Distribution. — Late Pliensbachian, Margaritatus chronozone, Stockesi subchronozone up to Spinatum chronozone, Hawskerense subchronozone. Haute-Marne: bed 3.

Diagnosis. - The adult size is small, ribbing is very weak or absent all along the growth. The keel is very low; chevrons are extremely weak and disappear at the end of the growth. The whorl section is elliptical to ovate.

\section{DisCUSSION}

According to Howarth (1958) and Tintant et al. (1961), the closest taxon to the genus Amauroceras is Amaltheus wertheri (Lange, 1932). Buckman (1913) considered these species as "degenerated Amaltheus". Some authors (Dommergues et al. 2008) included the species wertheri within Amauroceras. While the adult size of $A$. wertheri is similar to that of $A m$ auroceras specimens, its ribs are pronounced and its keel is that of Amaltheus. Amauroceras has been considered the microconch of Amaltheus (Callomon 1981; Comas-Rengifo 1985; Meister 1988) but while the total biostratigraphic ranges of these two genera seem to be similar, their occurrence together in a same bed is not the rule. Furthermore their relative abundances are different. The most common hypothesis is to consider the specimens of Amauroceras as "dwarf Amaltheus" resulting from a hypomorphosis (Reilley et al. 1997).

\section{Amauroceras ferrugineum (Simpson, 1855)}

$$
\text { (Fig. 5C, D, G, H) }
$$

Ammonites ferrugineus Simpson, 1855: 79.

Ammonites amaltheus laevis Quenstedt, 1856: 328, pl. 42, fig. 1.

Amauroceras ferrugineum - Buckman 1919: pl. 142, figs 1-5. - Howarth 1958: 24, pl. 4, figs 9-14. - Meister 1988: pl.3, fig. 9.

TYPE MATERIAL. - Simpson (1855) figured two syntypes, Buckman has selected one of them (Whitby museum, WHITM:SIM482.2) as the lectotype (1919: pl. 142).

SPeCimens AVAilable. - UPMC-139, 140.

STRATigraphical Distribution. - Late Pliensbachian, Margaritatus chronozone, Stockesi subchronozone up to Spinatum chronozone, Hawskerense subchronozone. Haute-Marne: bed 2 to 3 . 


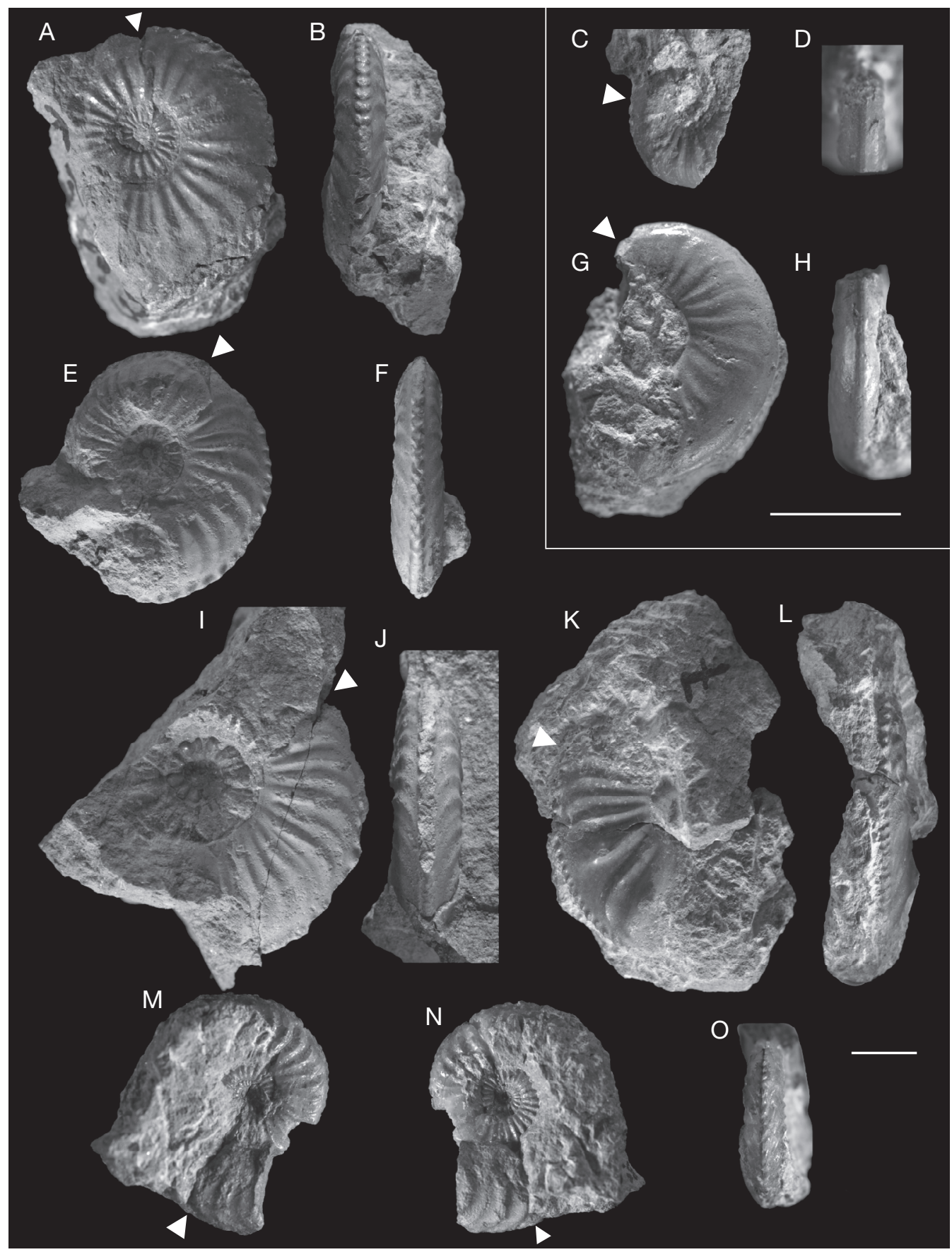

FIG. 5. - Amaltheus margaritatus Montfort, 1808: A, B, specimen UPMC-104, Outcrop 1, bed 3; E, F, specimen UPMC-147, Outcrop 1, bed 5. Amaltheus gibbosus (Schlotheim, 1820); I, J, specimen UPMC-148, Outcrop 1, bed 5; Amauroceras ferrugineum (Simpson, 1855); C, D, specimen UPMC-140, Outcrop 1, bed 3; G, H, specimen UPMC-139, Outcrop 1, bed 3. Amaltheus salebrosum Hyatt, 1867; K, L, specimen UPMC-225, Outcrop 1, bed 7. Pleuroceras transiens (Frentzen, 1937); M, O, specimen UPMC-174, Outcrop 1, beds 8,9 . Scale bars: $1 \mathrm{~cm}$. The arrows indicate the beginning of the body chamber. 
Geographic distribution. - England and Scotland (Howarth 1958); South- East France, Causses (Monestier 1913, 1916, 1928; Mattéi 1985; Meister 1989; Morard 2004); eastern France, Burgundy (Tintant et al. 1961) and Haute-Marne (this work); Northwest Germany (Jordan 1971); South-West Germany (Frentzen 1934; Urlichs 1977); South-East Germany (Hoffman et al. 2007).

\section{DESCRIPTION}

Involute shell ( $2 / 3$ of the previous whorl recovered) reaching the diameter of $50 \mathrm{~mm}$. Ornamentation is reduced to striae. The ventral area is angular with a gentle keel.

\section{DisCUSSION}

This species differs from Amaltheus engelhardti (d'Orbigny, 1844) and Amauroceras lenticulare (Young \& Bird, 1828) because of its less involute shell and its smaller size.

\section{Genus Pleuroceras Hyatt, 1867}

Paltopleuroceras Buckman, 1898: 453 (objective synonym).

TYPE SPECIES. - Ammonites spinatus Bruguière, 1789 (by subsequent designation of Fischer [1887]).

StratigraphicAl DisTRIBUTIONS. - Late Pliensbachian, Margaritatus chronozone, top of the Gibbosus subchronozone up to Spinatum chronozone, end of the Hawskerense subchronozone. Haute-Marne: bed 8 to 16a (first outcrop) and bed 20 to 32 (second outcrop).

Diagnosis. - The shell is evolute with elliptical to quadrilateral whorl sections. The ventral area brings a strong, crenulated keel bordered by flat areas or shallow to deep sulci. These are formed by projected sharpraised ribs on the ventro-lateral margin of the whorl. In some specimens or during the ontogeny the keel can lose crenulations to become smooth. On the flanks, the ornamentation consists in strong ribs that can develop tubercles on the ventro-lateral edge and can be raised near the umbilical edge.

\section{Pleuroceras transiens (Frentzen, 1937) (Figs 5M-O; 6A-E; Table 3)}

Amaltheus margaritatus var. transiens Frentzen, 1937: 99, pl. 4, figs 22-27.
Pleuroceras transiens - Howarth 1958: pl. 4, figs 16, 17. ? Bourdenet 1964: pl. 1, figs 1, 2. — Mattéi 1985: pl. 9, fig. 3. - Meister 1988: pl. 6, figs 4, 5.

Type Material. - The specimen of Frentzen (1937: pl. 4, fig. 26) has been secondly designated as lectotype by Howarth (1956).

SPECIMENS AVAILABLE. — UPMC-165-167, 174-182, 184.

Stratigraphical Distribution. - Late Pliensbachian. This species occurs close to the boundary between the Margaritatus and Spinatum Chronozones. Haute-HauteMarne: bed 8 up to 9 .

GeOgraphic DisTribution. - South-East France, Causses (Monestier 1913, 1916, 1928; Mattéi 1985; Meister 1989; Morard 2004); eastern France, Burgundy (Tintant $e t a l$. 1961), Franche-Comté (Bourdenet 1964) and Haute-Marne (this work); North-West Germany (Jordan 1971); SouthWest Germany (Frentzen 1934; Urlichs 1977); South-East Germany (Hoffman et al. 2007); Scotland (Howarth 1958); Italy, Lombardy Basin (Wiendenmayer 1980).

\section{DESCRIPTION}

The shell is moderately evolute with quadrilateral whorl section and rounded ventro-lateral edges. Ribs are relatively strong without the typical ventrolateral sharp-raised ribs of Pleuroceras. The keel is crenulated by strong individualized chevrons sometimes in connection with ribs.

\section{DISCUSSION}

Pleuroceras transiens differs from $A$. margaritatus by the lower whorl section, associated to a stronger forward projection of the ribs on the ventro-lateral edge. Other species of Pleuroceras have sharp-raised ribs on this ventro-lateral edge. Howarth (1956) designated the specimen (Quenstedt 1885: pl. XLI, fig. 5) as the lectotype of $A$. bechteri, thus $A$. bechteri is a synonym of $A$. salebrosum.

Pleuroceras solare s.s. (Phillips, 1829) (Fig. 7B, C; Table 3)

Ammonites solaris Phillips, 1829: 135, pl. 4, fig. 29.

Ammonites regularis Simpson, 1855: 89.

Ammonites costatus nudus Quenstedt, 1885: 334, pl. 42, fig. 19. 


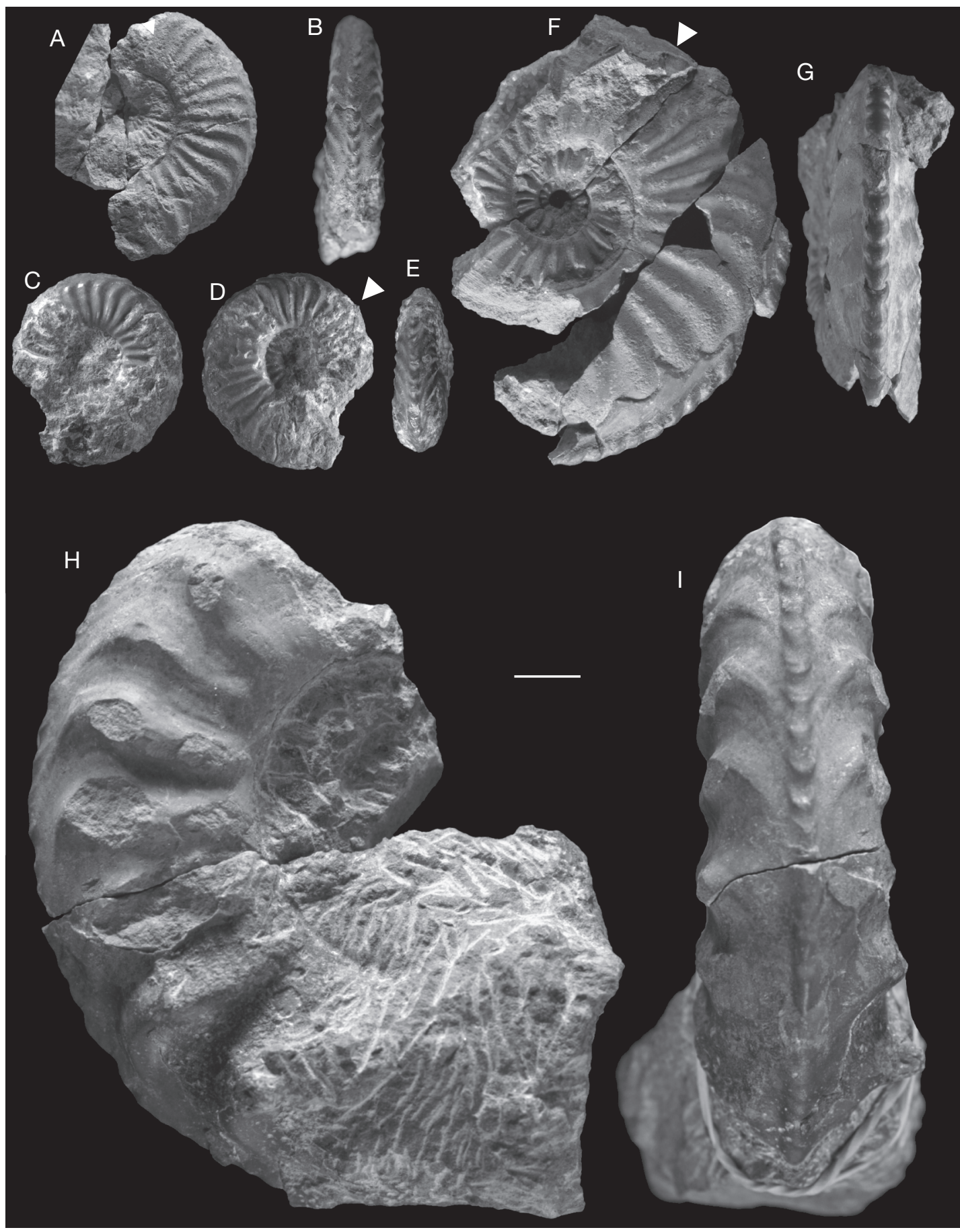

FIG. 6. - Pleuroceras transiens (Frentzen, 1937): A, B, specimen UPMC-175, Outcrop 1, bed 8, 9; C, D, E, specimen UPMC-176, Outcrop 1, bed 8, 9. Amaltheus margaritatus Montfort, 1808; F, G, specimen UPMC-187, Outcrop 1, bed 13. Amaltheus salebrosum Hyatt, 1867; H, I, specimen UPMC-188, Outcrop 1, bed 13. Scale bar: $1 \mathrm{~cm}$. The arrows indicate the beginning of the body chamber. 
Paltopleuroceras pseudocostatum - Richardson 1904: 215, pl. 24, fig. 10. — Buckman S. S. 1913: pl. 77.

Amaltheus bechteri Frentzen stad. nudum - Frentzen 1937: 106, pl. IV, fig. 32; pl. V, figs 4, 14; pl. IV, figs $3,4,7$.

Pleuroceras solare - Howarth 1958: 28, pl. V, figs 1-7, 10. - Tintant et al. 1961: pl. I, fig. 5. - Bourdenet 1964: pl. 1, fig. 3. - Mattéi 1985: pl. XII, fig. 7. Meister 1988: pl. 6, figs 6-11.

TYPE MATERIAL. - The holotype is the specimen figured by Phillips (1829: 135, pl. 4, fig. 29) and is now presumed to be lost. Howarth (1958: 28, pl. V, fig. 1) specimen has been designated as neotype (Sedgwick Museum of Earth Sciences, SM.J44277).

SPeCimens aVAilable. - UPMC-186, 190, 193-195.

Stratigraphical Distribution. — Late Pliensbachian, Spinatum chronozone, base of Apyrenum subchronozone up to the beginning of Hawskerense subchronozone. Haute-Marne: bed 8 or 13 to $16 \mathrm{a}$.

Geographic Distribution. - South-East France (Monestier 1913, 1916, 1928; Mattéi 1985; Meister 1989; Morard 2004); eastern France, Burgundy (Tintant et al. 1961; Lablanche et al. 1997), Franche-Comté (Bourdenet 1964) and Haute-Marne (this work); North-West France, Paris Basin, Normandy (Dommergues 2008); North-West Germany (Jordan 1971); South-West Germany (Frentzen 1934); South-East Germany (Hoffman et al. 2007); England (Howarth 1958); Spain, Betic Range (Comas-Rengifo et al. 2010 ); Portugal (Mouterde 1967); Italy, Lombardy Basin (Wiendenmayer 1980); Morocco, Moyen-Atlas (Morard 2004).

\section{DESCRIPTION}

Evolute shells with whorls slightly higher than large. Demarcation of ventro-lateral edge can occur late in the ontogeny and be slightly pronounced. Sometimes, small tubercles can be observed up to a diameter of $20 \mathrm{~mm}$. Ribs are sharp-raised.

\section{Pleuroceras solare solitarium (Simpson, 1855)} (Table 3)

Ammonites solitarius Simpson, 1855: 83; 1884: 133.

Paltopleuroceras solitarium - Buckman 1912: pl. 52.

? Amaltheus solitarius - Frentzen 1937: pl. 6, figs 8-11.
? Amaltheus solitarius var. tuberculata - Frentzen 1937: pl. 6, figs 12, 13.

Pleuroceras solare var. solitarium - Howarth 1958: 31, pl.5, fig. 10. — ? Bourdenet 1964: pl. 1, fig. 5.

TYPe MATERIAL. - The holotype (Whitby museum, WHITM:WM500) described by Simpson (1855: 93) is the specimen figured by Buckman (1912: pl. 52).

SPecimen aVAilable. — UPMC-203.

Stratigraphical Distribution. - Apyrenum subchronozone. Haute-Marne: bed 16a.

Geographic Distribution. - Eastern France, FrancheComté (Bourdenet 1964) and Haute-Marne (this work); North-West Germany (Jordan 1971); South-West Germany (Frentzen 1934); England (Howarth 1958); Morocco, Moyen-Atlas (Morard 2004).

\section{DESCRIPTION}

The shell is evolute with a whorl section higher than large. The distinction of the ventro-lateral edge can occur late in the ontogeny and be slightly pronounced. Whorl section is trapezoid: whorl breadth on ventro-lateral edges is inferior to the one on dorso-ventral edges. Small tubercles can be observed up to a diameter of $20 \mathrm{~mm}$. Ribs are sharp-raised.

\section{DISCUSSION}

Our specimen can be identified as $P$. solare solitarium because it shows tubercles in the inner whorls and a decreasing rib density along the growth. However, first, its whorl section is not as high as specimens undoubtedly attributed to $P$. solare solitarium; second, rib density is intermediate between $P$. solare and P. spinatum. Tubercles are reduced starting from a diameter of $40 \mathrm{~mm}$. The identification problem is similar to the one discussed for $A$. margaritatus s.s. and $A$. gibbosus. It is necessary to study the extension of these ontogenetic stages to confirm the existence of different morphological taxa ranked at the species level or higher. Few specimens of this taxon have been found (Simpson 1855; Buckman 1912; Frentzen 1937; Howarth 1958; Bourdenet 1964). Because of its uncertain identification, this specimen has not been taken into account for the biostratigraphic discussion. 


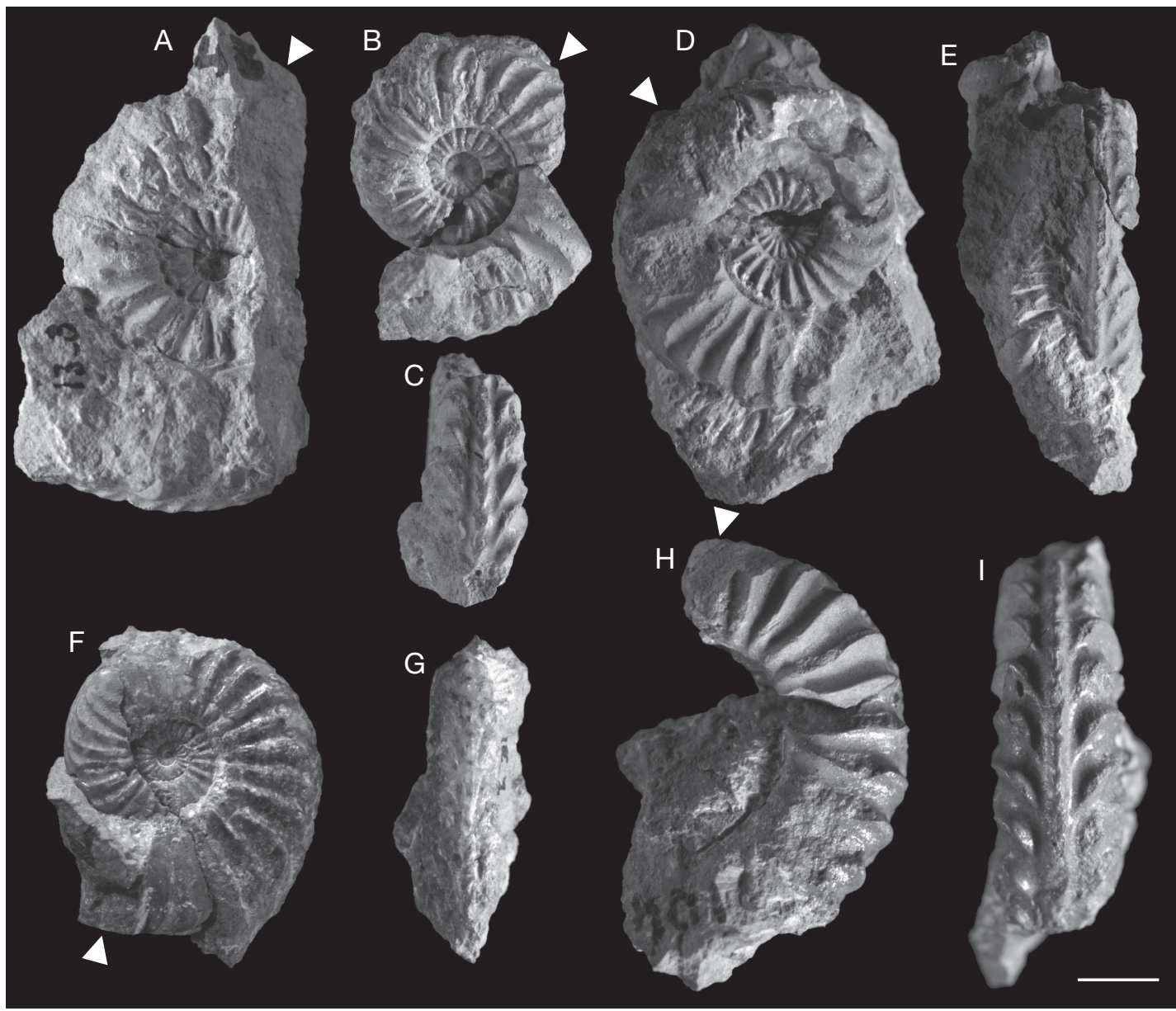

FIG. 7. - Pleuroceras spinatum (Bruguière, 1789): A, specimen UPMC-189, Outcrop 1, bed 13. Pleuroceras solare (Phillips, 1829); B, C, specimen UPMC-190, Outcrop 1, bed 13; D, E, specimen UPMC-200, Outcrop 1, bed 16. Pleuroceras solare trapezoidiforme (Maubeuge, 1951); F, G, specimen UPMC-202, Outcrop 1, bed 16. Pleuroceras cf. spinatum (Bruguière, 1789); H, I, specimen UPMC201, Outcrop 1, bed 16 . Scale bar: $1 \mathrm{~cm}$. The arrows indicate the beginning of the body chamber.

\section{Pleuroceras solare trapezoidiforme}

(Maubeuge, 1951)

(Fig. 7F, G; Table 3)

Paltopleuroceras trapezoidiformis Maubeuge, 1951: 5, pl. 1, fig. 4a-c.

Pleuroceras solare var. trapezoidiforme - Howarth 1958: 30, pl. 5, figs 8, 9. - Bourdenet 1964: pl. 1, fig. 4.

TYPE MATERIAL. - The holotype is the specimen figured by Maubeuge (1951: 5, pl. 1, fig. 4a-c).

SPECIMENS AVAILABle. — UPMC-191, 202.
Stratigraphical Distribution. - Upper Apyrenum subchronozone. Haute-Marne: bed 13 to 16a.

Geographic Distribution. - Eastern France, FrancheComté (Bourdenet 1964) and Haute-Marne (this work); North-West Germany (Jordan 1971); England (Howarth 1958); Belgium, Ardennes (Maubeuge 1951); Italy, Lombardy Basin (Wiendenmayer 1980).

\section{DESCRIPTION}

Evolute shell, with whorl section higher than large. The development of the ventro-lateral edge can occur 
late in the ontogeny and be slightly pronounced. Whorl section is trapezoid, breadth on ventro-lateral edges inferior to dorso-ventral edges. Sometimes, small tubercles up to a diameter of $20 \mathrm{~mm}$. Ribs are sharp-raised.

Pleuroceras spinatum (Bruguière, 1789) (Figs 7A; 8A-E; Table 3)

Ammonites spinata Bruguière, 1789: 40.

Ammonites franconicus Schlotheim, 1813: 101.

Nautilus franconicus Reinecke, 1818: 87, pl. 9, figs 68, 69.

Ammonites costatus Schlotheim, 1820: 68.

Ammonites spinatus - d'Orbigny 1844: 209, pl. 52, figs 1-3.

Ammonites costatus spinatus Quenstedt, 1849: 95, pl. 5 , fig. 10a, b.

Pleuroceras costatum - Hyatt 1867: 89.

Pleuroceras pseudospinatum Hyatt, 1867: 90 (nom. nov. for Quenstedt, 1849: pl. 5, fig. 10; 1856: pl. 21, figs 1-3).

Ammonites amaltheus spinatus Quenstedt, 1885: 333, 335, pl. 42, figs 17, 18, 25, 27.

Ammonites costatus nudus Quenstedt, 1885: 335, pl. 42, fig. 26.

Paltopleurocerasspinatum - Arkell 1933: 604, pl. 31, fig. 1.

Pleurocerasspinatum - Howarth 1958: 37, pl. 7, figs 2-6. Tintant et al. 1961: pl. 1, fig. 9. - Bourdenet 1964: pl. 1, figs 9-11. - Meister 1988: pl. 8, figs 5, 6, 10, pl. 9, figs 1, 2.

Type Material. - The neotype (Sedgwick Museum of Earth Sciences, SM.J35923) has been designated by Howarth (1958: pl. VII, fig. 2).

SPeCimens aVAILABLE. - UPMC-189, 201, 208, 209, $211,217,219,220$.

Stratigraphical Distribution. - Upper Apyrenum subchronozone to Hawskerense subchronozone. HauteMarne: bed 13 (first outcrop) and bed 20 to 32 (second outcrop).

Geographic Distribution. - South-East France (Monestier 1913, 1916, 1928; Mattéi 1985; Meister 1989; Morard 2004); eastern France, Burgundy (Tintant et al. 1961; Lablanche et al. 1997), Franche-Comté
(Bourdenet 1964) and Haute-Marne (this work); NorthWest Germany (Jordan 1971); South-West Germany (Frentzen 1934); South-East Germany (Hoffman et al. 2007); Switzerland, Prealps (Dommmergues et al. 1990); England (Howarth 1958); Spain, Betic Range (ComasRengifo et al. 2010); Portugal (Mouterde 1967); Italy, Lombardy Basin (Wiendenmayer 1980); Georgia (Topchishvili 1998);

\section{DESCRIPTION}

Evolute forms with quadrilateral and massive whorls. Adult size can reach $30 \mathrm{~cm}$. Ribs are strong, straight on the flank and sharp-topped and projected forward on the ventral area. Rib density is weak. The keel is high. A tubercle develops on each rib slightly dorsal than the sharp-topped part.

\section{DISCUSSION}

ABOUT $A$. GR. MARGARITATUS AND P. GR. SOLARE The genus Amaltheus shows a wide disparity. Consequently, many species have been created to account for this disparity (28 species in the XIX'th), (Young \& Bird 1828; Quenstedt 1849, 1856, 1882$1885)$. With the development of new concepts in systematics, paleontologists have tried to explain this disparity as a result of an evolutionary process. Morphological continuums have been searched to identify species. Several authors recognize a morphological continuum between Amaltheus species (Frentzen 1937; Mattéi 1985; Meister 1988) and considered $A$. gr. margaritatus generally including Amaltheus margaritatus, Amaltheus subnodosus (Young \& Bird, 1828), Amaltheus gloriosus Hyatt, 1867, Amaltheus gibbosus, Amaltheus salebrosum and according to Meister (1988), Amaltheus evolutus Buckman, 1912, Amaltheus bondonniensis Meister, 1986 and Amaltheus striatus Howarth, 1955. These three species are included in the $A$. gr. margaritatus when they are not considered as synonyms of the species mentioned among the first five species in the list.

The disparity between these species concern mainly two aspects: the strength of the ornamentation and the extension of the different ontogenetic stages. Concerning the strength of the ornamentation, some authors invoke Buckman's law, which states that the 


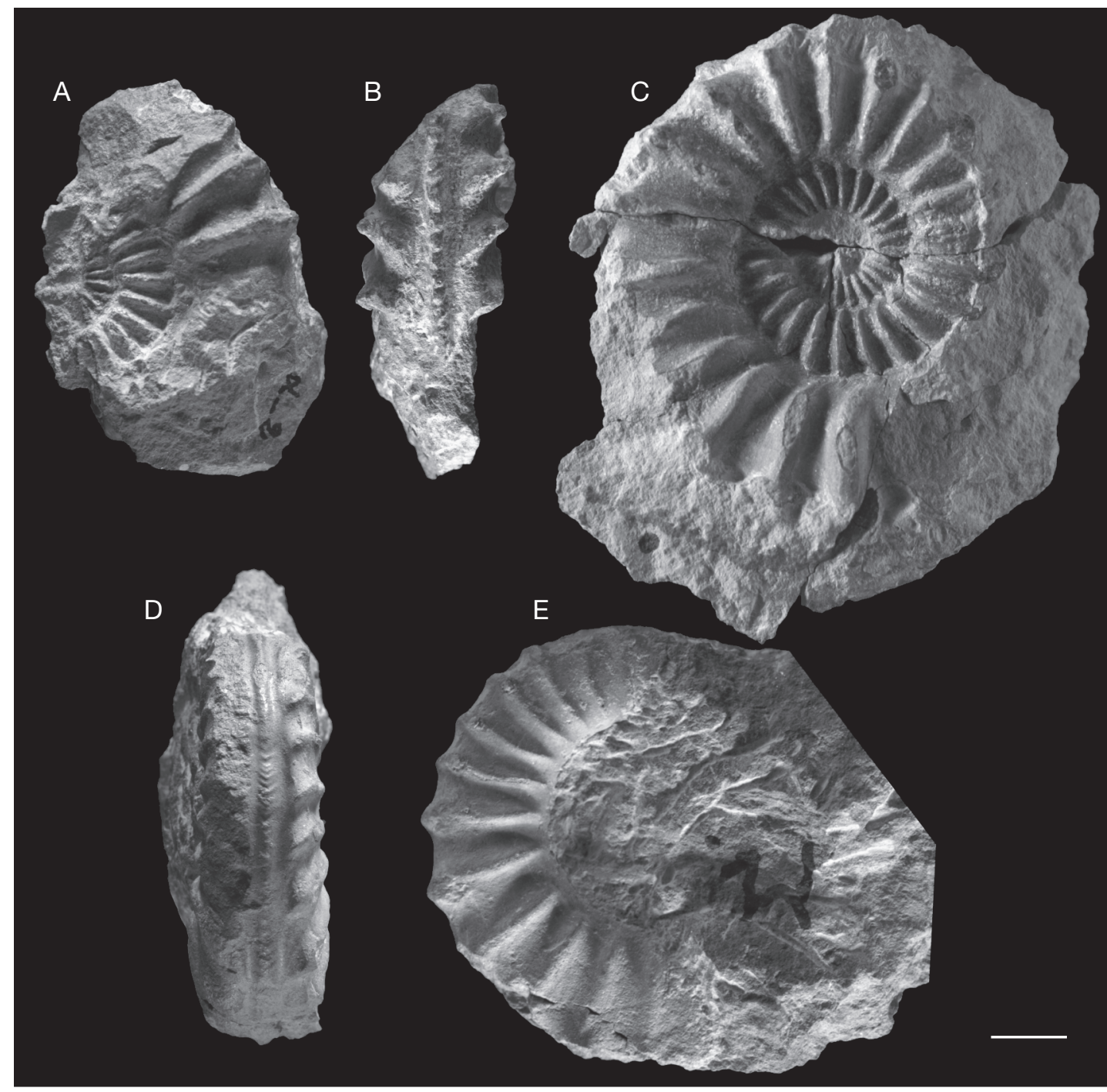

FIG. 8. - Pleuroceras spinatum (Bruguière, 1789): A, B, specimen UPMC-209, Outcrop 1, bed 20; C, specimen UPMC-208; D, E, specimen UPMC-220, Outcrop 1, bed 20 . Scale bar: $1 \mathrm{~cm}$.

strength of the ornamentation correlates negatively with the degrees of compression and involution of the shell (i.e. Buckman 1892; Westermann 1966; Guex et al. 2003; Hammer \& Bucher 2005). To date, there is no study assessing to what degree Buckman's law explains the disparity, confirming the existence of several species only on the basis of the ornamentation strength. The other ambiguity in the definition of several species resides in the extension of the different ontogenetic stages. Several authors (i.e. Quenstedt 1885; Frentzen 1937) have shown that different taxons develop some identical ontogenetic stages, whose limits have never been clearly defined. For example, on the one hand, some specimens of $A$. margaritatus s.s. develop all types of tubercles (like tubercles observed in A. gibbosus, 
A. subnodosus, A. gloriosus) (Tintant et al. 1961) in the inner whorls. On the other hand, the species $A$. gibbosus, $A$. subnodosus, $A$. gloriosus can have a mature stage resembling $A$. margaritatus s.s. As long as no study with robust statistical characterization of the extension of the stages exists, any decision concerning the taxonomic status of Amaltheus gr. margaritatus and the included taxa seems to be subjective. The same problem exists for taxa included Pleuroceras gr. solare (i.e. apyrenum (Buckman, 1911), quadratum (Howarth, 1958), trapezoidiforme, solitarium and sometimes spinatum, yeovilense (Howarth, 1958)). Despite these uncertainties, these taxa have been used in the present work (at specific or subspecific rank) because of their biostratigraphic significance. These uncertainties likely have an impact in both evolutionary and diversity studies. However, as previously mentioned, a thorough quantitative study is needed to resolve these problems.

About PleUROCERAS TRANSIENS (FRENTZEN, 1937) AND AMALTHEUS BECHTERI FRENTZEN, 1934

Frentzen (1937) defined Amaltheus margaritatus var. transiens as morphological transition between A. margaritatus and A. bechteri. Amaltheus bechteri was a taxon including many forms currently subdivided in two species ( $A$. salebrosum, $P$. solare). Today, P. transiens is considered transitional between A. margaritatus and $P$. solare. This anagenetic pattern has been recognized by several authors (i.e. Frentzen 1937; Howarth 1958; Tintant et al. 1961). Consequently, a clear definition of $P$. transiens is impossible, and many figured specimens have been identified as P. transiens, whereas their morphologies are more similar to the specimens described by Frentzen as A. bechteri. This remark justifies that the boundary between the Margaritatus-schichten and Bechterischichten of Frentzen (1934) coincides with the boundary between the Gibbosus subchronozone and the Apyrenum subchronozone of the GFEJ (Dommergues et al. 1997), despite the position of P. transiens at the top of the Margaritatus-schichten for Frentzen and at the base of the Apyrenum subchronozone in the current zonation. Howarth (1956) designated the specimen (Quenstedt 1885: pl. XLI, fig. 5) as the lectotype of $A$. bechteri, thus $A$. bechteri is a synonym of $A$. salebrosum (Table 2 ).

\section{PALAEOBIOGEOGRAPHY}

The ammonites described in this work belong to the Euroboreal fauna (Dommergues 1987) that defines the Boreal Realm in the early Jurassic (Hallam 1975). The dominance of representatives of the family Amaltheidae is quite common in France for non-alpine localities, where rare representatives of the Tethyan family Hildoceratidae have been reported (Dommergues \& Meister 1991). The palaeobiogeographic relations between Tethyan and Euroboreal ammonites during the Pliensbachian have already been discussed in detail by Dommergues \& Meister (1991) on the basis of the relative abundance of the different ammonite families in selected palaeogeographic areas. It is worth noting that in the "Lac de Charmes" no representatives of Hildoceratidae have been found. Because of the extensive field work that has been done, we assume that this absence is genuine but we cannot rule out the possibility that it is due to sampling failure.

Three factors, which can combine each other, account for the occurrence of these Tethyan representatives in the area studied in the present work: palaeolatitude, time, palaeonvironment.

Rare Hildoceratidae are known to occur in Western European areas that during the early Jurassic were located in the palaeolatitudinal interval between 30 and $35^{\circ} \mathrm{N}$ (Dercourt et al. 2000): Causses area (Mattéi 1985; Meister 1989), Burgundy (Tintant et al. 1961), Normandy (Dubar in Howarth 1955; Dommergues et al. 2008), southern Germany (Urlichs 1977). They also occur in Yorkshire (Howarth 1955), which was located between 35 and $40^{\circ} \mathrm{N}$ (Dercourt et al. 2000). Palaeolatitude does not seem to explain the absence of Hildoceratidae in the "Lac de Charmes".

The arrival of Tethyan representatives in areas dominated by typical Euroboreal ammonites could be related to factors that changed during the time (Cecca 1988). Dommergues \& Meister (1991) showed decreasing proportions of Hildoceratidae in Causses and Burgundy from the Stokesi to the Spinatum chronozones. The necessary biostratigraphic information is not always available in the literature, and the most reliable datings show that Hildoceratidae occur in the Spinatum chronozone 
of Yorkshire (Howarth 1955) and in the Gibbosus subchronozone of southern Germany (Urlichs 1977) and, possibly Normandy (Dommergues et al. 2008). These occurrences of Hildoceratidae span the same time interval represented by the succession exposed in the outcrops of the "Lac de Charmes". As Hildoceratidae mainly occurred in epioceanic environments of the Tethys, their absence in our study area seems related to palaeoenvironmental conditions, likely shallower depths suggested by the abundance of benthic taxa.

In conclusion, the absence of Hildoceratidae in our study area probably reflects ecologic, more than biogeographic, causes. The same holds true for the absence of representatives of other ammonites belonging to the suborders Phylloceratina and Lytoceratina, which were linked to oceanic environments (Dommergues 1987; Dommergues \& Meister 1991).

\section{Acknowledgements}

We are indebted to Jean-Louis Dommergues (Dijon), Christian Meister (Geneva), Kevin Page (Plymouth) and Annemarie Ohler (Paris) for their useful comments and suggestions that considerably improved the manuscript. We also thanks Cidalina Gomez, Malcolm Sanders and Sébastien Huertas who helped us to collect the ammonites. A special thank to Alexandre Lethiers, who took the photographs and realized the figures. We also thank Mélanie Kenney for improving the English.

\section{REFERENCES}

ARKELL W. K. 1933. - The Jurassic System in Great Britain. Clarendon Press, Oxford, 681 p.

Bourdenet A. M. 1964. - Les Pleuroceras du Domérien supérieur de Charmoille (Haute-Saône). Annales scientifiques de l'Université de Besançon, $2^{e}$ série, Géologie 18: 3-24.

BRANDT K. 1985. - Sea-level changes in the upper Sinemurian and Pliensbachian of southern Germany, in BAYER U. \& SeIlacher A. (eds), Sedimentary and evolutionary cycles. Springer Verlag, 113-126.

BRANDT K. 1986. - Glacioeustatic cycles in the early Jurassic? Neues Jahrbuch für Geologie und Paläontologie, Monatshefte 1986 (5): 257-274.
BRUGUière J. G. 1789-1832. - Encyclopédie méthodique ou par ordre des matières: Histoire naturelle des vers, des coquilles et des mollusques. Paris.

BUCKMAN S. S. 1887-1907. - A Monograph of the Ammonites of the Inferior Oolite Series. The Paleontological society, London, $456 \mathrm{p}$.

BUCKMAN S. S. 1909-1930. - Yorkshire type ammonites. Wheldon and Wesley, London, $185 \mathrm{p}$.

BuCKMAN S. S. 1918. - Jurassic chronology: I-Lias. Quarterly Journal of the Geological Society of London 73: 257-327.

Callomon J. H. 1981. - Dimorphism in ammonoids. Systematics Association Special Volume 18 (9): 257-273.

CECCA F. 1988. - Ammonites méditerranéennes du Tithonique inférieur de l'Ardèche (Sud-Est de la France): analyse des afflux téthysiens. Geobios 21: 169-186.

Comas-Rengifo M. J. 1985. - El Pliensbachiense de la cordillera ibérica. Doctoral thesis, Universidad complutense, Madrid, 591 p. [unpublished]

DaGIs A. A. 1976. - Late Pliensbachian ammonites (Amaltheidae) of the North Siberia. Academy of Sciences of the U.R.S.S. Siberian branch. Transactions of the Institute of Geology and Geophysics, Novosibirsk, 79 p.

Dean W. T., Donovan D. T. \& Howarth M. K. 1961. - The liassic ammonite zones and subzones of the north-west European province. Bulletin of the British Museum 4 (10): 437-505.

Dercourt J., Gaetani M., Vrielynck B., Barrier E., Biju-Duval B., Brunet M. F., Cadet J. P., Crasquin S. \& Sandulescu M. 2000. - Atlas PeriTethys, Palaeogeographical Maps. Comité de la Carte Géologique du Monde/Committe of the Geological Map of the World, Paris.

DommergueS J.-L. 1987. — Lévolution chez les Ammonitina du Lias moyen (Carixien, Domérien basal) en Europe occidentale. Documents des Laboratoires de Géologie de Lyon 5 (4): 355-407.

Dommergues J.-L. \& Meister C. 1991. — Area of mixed marine faunas between two major paleogeographical realms, exemplified by the Early Jurassic (Late Sinemurian and Pliensbachian) ammonites in the Alps. Palaeogeography, Palaeoclimatology, Palaeoecology 86: 265-282.

Dommergues J.-L., Meister C. \& Mettraux M. 1990. - Succession des faunes d'ammonites du Sinémurien et du Pliensbachien dans les préalpes médianes de Suisse Romande (Vaud et Fribourg). Geobios 23 (3): 307-341.

Dommergues J.-L., Meister C. \& Mouterde R. 1997. - Pliensbachien, in CARIOU E. P. H. (eds), Biostratigraphie du jurassique ouest-européen et méditerranéen: Zonations parallèles et distribution des invertébrés et microfossiles. Bulletin du Centre Recherche Elf, Exploration et Production, Mémoires 17: 15-23. 
Dommergues J.-L., Dugué O., Gauthier H., Meister C., Neige P., Raynaud D., Savary X. \& Trevisan M. 2008. - Les ammonites du Pliensbachien et du Toarcien basal dans la carrière de la Roche Blain (Fresnay-le-Puceux, Calvados, Basse-Normandie, France). Taxonomie, implications stratigraphiques et paléobiogéographiques. Revue de Paléobiologie, Genève 27 (1): 265-329.

Efimova A. F., Kinasov V. P., Paraketsov K. V., PolUBOTKO I. V., REPIN Y. S. \& DAGIS A. S. 1968. - Field atlas of the Jurassic fauna and flora of the North-East of the USSR. Magadan. 379 p. (in Russian).

Faure P., Almeras Y., Sekatni N. \& Zargouni F. 2007. — Le Pliensbachien de Jebel Zaghouan (Tunisie). Nouvelles données fauniques. Implications biostratigraphiques et paléobiogéographiques. Geodiversitas 29 (4): 473-506.

FISCHER J.-C. 1994. - Révision critique de la Paléontologie française d'Alcide d'Orbigny incluant la réédition de l'original. Volume 1. Céphalopodes jurassiques. Masson, Paris, 340 p.

FISCHER P. 1887. - Manuel de conchyliologie et de paléontologie conchyliologique, ou histoire naturelle des mollusques vivants et fossiles. Librairie F. Savy, Paris, 1369 p.

Frentzen K. 1934. - Der Lias Delta (AmaltheenSchichten) im Gebiete zwischen Aselfingen und Aalen. Sitzungsberichte der Heidelberger Akademie der Wissenschaften, Mathematisch-naturwissenschaftiche Klasse 1934 (2): 1-73.

Frentzen K. 1937. - Ontogenie, Phylogenie und Systematik der Amaltheen des Lias Delta Südwestdeutschlands. Abhandlungen der Heidelberger Akademie der Wisssenschaften, Mathematisch-naturwissenschaftiche Klasse 23: 1-136.

Giebel C. G. 1852. - Fauna der Vorwelt mit steter Berücksichtigung der lebenden Thiere-Cephalopoden. Friedrich Arnold Brockhaus, Leipzig, 856 p.

Guex J., Koch A., O’dogherty L. \& Bucher H. 2003. - A morphogenetic explanation of Buckman's law of covariation. Bulletin de la Société Géologique de France 174 (6): 603-606.

Hallam A. 1975. - Jurassic Environments. Cambridge University Press, Cambridge, 278 p.

Hammer Ø. \& BuCHER H. 2005. - Buckman's law of covariation - a case of proportionality. Lethaia 38: 67-72.

Hoffmann R., Keupp H. \& GradL H. 2007. - Zur Korrelation der Lias-Tongruben von Unterstürmig und Buttenheim (Frankenalb). Jahresberichte und Mitteilungen des Oberrheinischen Geologischen Vereins 89: 37-48.

HowARTH M. K. 1955. - Domerian of the Yorkshire coast. Proceedings of the Yorkshire Geological Society 30 (2): 147-175.

HOWARTH M. K. 1956. - The Scalpa sandstone of the isle of Raasay. Proceedings of the Geological Society of
London 30: 353-370.

HOWARTH M. K. 1957. — The middle Lias of the Dorset coast. Quarterly Journal of the Geological Society 113 (1-4): 185-202, NP, 203, 204.

Howarth M. K. 1958. - A Monograph of the Ammonites of the Liassic Family Amaltheidae in Britain. (Part 1) 111; (Part 2) 112. Palaeontological Society, London: 1-26, 27-53.

HүAтT A. 1867. - The fossil cephalopods of the Museum of Comparative Zoology. Bulletin of the Museum of Comparative Zoology 1: 71-102.

JORDAN R. 1971. — Zur Stratigraphie und zur Paläontologie des Ammoniten des oberen Pliensbachium (Jura, Domerium, Lias Delta Nordwest-Deutschlands. Mémoires du Bureau de recherches géologiques et minières 75: 521-532.

KuHn O. 1935. - Die Fauna des untersten Lias, (Gibbosus-zone) aus dem Sendelbach im Hauptmoorwald östlich Bamberg. Neues Jahrbuch für Mineralogie, Geologie und Paläontologie, Abhandlungen B3: 465-493.

LABlanCHE G., LEFAVRAIS-RAYMOND A. \& DELANCE J. H. 1997 — Le Domérien et le Toarcien basal au nord du horst de Saint-Saulge (Nièvre). Géologie de la France 2: 51-54.

LANGE W. 1932. — Über ein Hammatoceras und einen Amaltheenvorläufer (Proamaltheus wertheri gen. nov. sp. nov.) aus dem Lias Gamma+Delta von Werther in Westphalen. Zeitschrift der Deutschen Geologischen Gesellschaft 84 (4): 235-241.

MatTei J. 1985. - Application de méthodes d'analyse globale à l'étude des Amaltheidae du bassin sédimentaire des Causses (Carixien supérieur et Domérien). Éditions du Centre National de la Recherche Scientifique, Paris, 146 p.

Maubeuge P. L. 1951. - Sur quelques ammonites rares ou nouvelles du Lias moyen de Belgique. Bulletin de l'Institut Royal des Sciences naturelles de Belgique 27 (55): 1-6.

Maubeuge P. L. 1958. - À propos du Domérien supérieur des environs de Langres (Haute-Marne). Édition Privée, Nancy, 4 p.

Maubeuge P. L. 1961. - Le Toarcien et le sommet du Pliensbachien dans la région de Langres (Hte marne) et quelques comparaisons avec la Lorraine centrale. Colloque du Lias français. Chambéry 1960. Mémoires du Bureau de recherches géologiques et minières 4: 563-576.

Meister C. 1986. - Les ammonites du Carixien de Causses (France). Mémoires suisses de Paléontologie 109: 1-209.

MeISTER C. 1987. - Comparaison des faunes d'ammonites au Domérien (Jurassique inférieur) entre le Bassin des Causses et les Cordillères Bétiques. Comptes-Rendus de l'Académie des Sciences, Paris 305 (5): 425-428.

Meister C. 1988. - Ontogenèse et évolution des Amaltheidae (Ammonoidea). Eclogae Geologicae Helvetiae 81 : 763-841. 
Meister C. 1989. - Les ammonites du Domérien des Causses (France); analyses paléontologiques et stratigraphiques. Éditions du Centre National de la Recherche Scientifique, Paris, 80 p.

Meister C. \& BÖHM. F. 1993. - Austroalpine Liassic Amonites from the Adnet Formation (Northern Calcareous Alps). Jahrbuch Der Geologischen BundsanstaltA 136: 163-211.

MONESTIER J. 1913. - Sur la stratigraphie paléontologique de la zone à Amaltheus margaritatus dans la région sud-est de l'Aveyron. Bulletin de la Société Géologique de France 13 (4): 1-8.

Monestier J. 1916. — Sur le Lias moyen de la région sud-est de l'Aveyron. Mémoires de la Société des Lettres, Sciences et Arts de l'Aveyron 18: 97-150.

MONESTIER J. 1928. — Recherches sur le polymorphisme et la phylogénie des Amalthéidés domériens d'après les matériaux aveyronnais. Mémoires de la Société des Lettres, Sciences et Arts de l'Aveyron 22: 61-90.

MonTFORT P. DENY DE 1808. - Conchyliologie systématique et classification méthodique des coquilles. Frédéric Schoell, Paris, 410 p.

Morard A. 2004. - Les événements du passage Domérien-Toarcien entre Téthys occidentale et Europe du Nord-Ouest. Thèse de doctorat, Université de Lausanne, vol. 2/2: paléontologie, Lausanne, 146 p. (unpublished).

Mouterde R. 1967. - Le Lias du Portugal. Vue d'ensemble et division en Zones. Comunicaçoes dos Serviços Geologicos de Portugal 52: 219-226.

Mouterde R., Enay R., CARIOU E., CONTINi D., Elmi S., Gabilly J., Mangold C., Mattei J., Rioult J., Thierry J. \& Tintant H. 1971. - Les zones du Jurassique en France. Comptes rendus de la Société Géologique de France 6: 76-102.

Oppel A. 1856-58. — Die Juraformation Englands, Frankreichs und des Südwestlichen Deutschlands. Würtemberger naturwissenschaftlichen Jahresheft 1214: 857.

Orbigny A. D'. 1844. - Paléontologie française: Terrains jurassiques, Tome 1, Céphalopodes. Masson, Paris, 17-27, 193-312.

Page K. N. 2003. - The lower Jurassic of Europe: Its subdivision and correlation. Geological Survey of Denmark and Greenland Bulletin 1: 223-259.

PHILLIPS J. 1829. - Illustrations of the Geology of Yorkshire. John Murray, York, $192 \mathrm{p}$.

QuenstedT F. A. 1845-1849. - Die Cephalopoden. Fues, Tübingen, $580 \mathrm{p}$.

QuenstedT F. A. 1856-1858. - Der Jura. Laupp, Tübingen, $842 \mathrm{p}$.

Quenstedt F. A. 1882-1885. - Die Ammoniten des schwäbischen Jura. I. Der schwarze Jura (Lias). Schweizerbart, Stuttgart, $440 \mathrm{p}$.

Reilley S. M., Wiley E. O. \& Meinhardt D. J. 1997. An integrative approach to heterochrony: the distinc- tion between interspecific and intraspecific phenomena. Biological Journal of the Linnean Society 60: 119-143.

REINECKE J. C. M. 1818. - Maris protogaei nautilos et argonautes vulgo cornua ammonis in agro coburgico et vicino reperiundos, descripcit et delineabit, silmu observationes des fossilium protypis. Coburgi, $90 \mathrm{p}$.

RiCHARDSON L. 1904. - A Handbook of the Geology of Cheltenham and Neighbourhood. Norman, Sawyer and Company, Cheltenham, 303 p.

SCHLOTHEIM E. F. VON 1813. - Beiträge zur Naturgeschichte der Versteinerungen in geognosticher Hinsicht. Leonhard's Taschenbuch der Mineralogie 7: 3-134.

Schlotheim E. F. VON 1820. — Die Petrefactenkunde auf ibrem jetzigen Standpunkte durch die Beschreibung seiner Sammlung versteinerter und fossiler Überreste des Thier- und Pflanzenreichs der Vorwelt. Becker, Gotha, 499 p.

Seyed-Emami K., FÜrsich F. T., Wilmsen M., MajidiFARD M. R. \& SHEKARIFARD A. 2008. - Lower and Middle Jurassic ammonoids of the Shemshak Group in Alborz, Iran and their palaeobiogeographical and biostratigraphical importance. Acta Palaeontologica Polonica 53 (2): 237-260.

SiMPSON M. 1843. - A Monograph of the Ammonites of the Yorkshire Lias. Simpkin, Marshall, London, $60 \mathrm{p}$.

SimPSON M. 1855. - The Fossils of the Yorkshire Lias, Described from Nature. Whittaker, Whitby \& London, $149 \mathrm{p}$.

Smith P. L., Tipper H. W. \& Ham D. M. 2001. — Lower Jurassic Amaltheidae (Ammonitina) in North America: paleobiogeography and tectonic implications. Canadian Journal of Earth Sciences 38 (10): 1439-1449.

Sowerby J. \& Sowerby J. D. C. 1812-1829. - The Mineral Conchology of Great Britain. B. Meredith, London, 1-3.

SpATH L. F. 1942. - The ammonite zones of the Lias. Geological Magazine 79: 264-268.

STEPHANOV J. 1960. - Representatives of the family Amaltheidae in Bulgaria. Travaux sur la géologie de Bulgarie, Série Paléontologie 2: 265-293.

TieTZE E. 1872. — Geologische und paläontologische Mittheilungen aus dem südlichen Theil des Banater Gebirgsstockes. Jahrbuch der kaiserlich-königlichen geologischen Reichsanstalt 22: 35-142.

Tintant H., Gauthier J. \& Lacroix L. 1961. — Les Amalthéidés de Côte-d'or et leur répartition stratigraphique. Bulletin scientifique de Bourgogne 20: 137-161.

TopCHISHVILI M. 1998. — Biostratigraphic characterization of Lower Jurassic deposits of Georgia by ammonites. Cuadernos de Geologia Ibérica 24: 277-291.

URLICHS M. 1977. - Stratigraphy, ammonite faunas and some ostrcods of the upper Pliensbachian at the type locality (Lias, SW-Germany). Stuttgarter Beiträge zur Naturkunde, Serie B 28: 1-13.

Westermann G. E. G. 1966. - Covariation and 
taxonomy of the Jurassic ammonite Sonninia adicra (Waagen). Neues Jahrbuch für Geologie und Paläontologie, Abhandlungen 124: 289-312.

Wiendenmayer F. 1980 - Die Ammoniten der mediterraneen Pronvinz im Pliensbachien und unteren Toarcien aufgrund neuer Untersuchungen im Generoso-Becken (Lombardische Alpen). Mé- moires de la Société helvétique des Sciences naturelles 93: 1-195.

WRIGHT T. 1878-1886. - Monograph on the "Lias ammonites" of the British islands. The Palaeontographical society, London, 503 p.

Young G. A. M. \& BIRD J. 1828. — A Geological Survey of the Yorkshire Coast. Clark, Whitby, 367 p.

Submitted on $3^{\text {rd }}$ April 2012; accepted on 7 September 2012; published on 28 June 2013. 